\title{
Induction of aquaporin 4-reactive antibodies in Lewis rats immunized with aquaporin 4 mimotopes
}

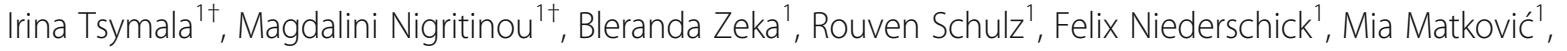 \\ Isabel J. Bauer ${ }^{1}$, Michael Szalay², Kathrin Schanda ${ }^{3}$, Magdalena Lerch³, Tatsuro Misu4, Kazuo Fujihara ${ }^{4}$, \\ Jeffrey L. Bennett ${ }^{5}$, Charlotte Dahle ${ }^{6}$, Florence Pache ${ }^{7}$, Paulus Rommer $^{8}$, Fritz Leutmezer ${ }^{8}$, Zsolt Illes ${ }^{9}$, \\ Maria Isabel Leite ${ }^{10}$, Jacqueline Palace ${ }^{10}$, Petra Scholze ${ }^{2}$, Markus Reindl $^{3}$, Hans Lassmann ${ }^{1}$ and Monika Bradl ${ }^{*}$
}

\begin{abstract}
Most cases of neuromyelitis optica spectrum disorders (NMOSD) harbor pathogenic autoantibodies against the water channel aquaporin 4 (AQP4). Binding of these antibodies to AQP4 on astrocytes initiates damage to these cells, which culminates in the formation of large tissue destructive lesions in the central nervous system (CNS). Consequently, untreated patients may become permanently blind or paralyzed. Studies on the induction and breakage of tolerance to AQP4 could be of great benefit for NMOSD patients. So far, however, all attempts to create suitable animal models by active sensitization have failed. We addressed this challenge and identified peptides, which mimic the conformational AQP4 epitopes recognized by pathogenic antibodies of NMOSD patients. Here we show that these mimotopes can induce the production of AQP4-reactive antibodies in Lewis rats. Hence, our results provide a conceptual framework for the formation of such antibodies in NMOSD patients, and aid to improve immunization strategies for the creation of animal models suitable for tolerance studies in this devastating disease.
\end{abstract}

Keywords: Neuromyelitis optica spectrum disorders, Antibodies, Mimotopes, Aquaporin 4, Infections, Animal model

\section{Introduction}

Pathogenic autoantibodies directed against the water channel aquaporin $4(\mathrm{AQP} 4)$ are found in the vast majority of patients with neuromyelitis optica spectrum disorders (NMOSD). In NMOSD, these autoantibodies bind to AQP4 on astrocytes [1,2], and induce damage of these cells by antibody-dependent and complementmediated (cellular) cytotoxicity. This leads to the formation of large astrocyte-destructive lesions in the central nervous system (CNS), followed by neuronal loss and

\footnotetext{
* Correspondence: monika.bradl@meduniwien.ac.at

† Irina Tsymala and Magdalini Nigritinou contributed equally to this work.

'Department Neuroimmunology, Medical University Vienna, Center for Brain Research, Spitalgasse 4, A-1090 Vienna, Austria

Full list of author information is available at the end of the article
}

secondary demyelination. Despite extensive research on NMOSD, the mechanisms behind the formation of pathogenic AQP4-specific antibodies remain elusive. Pathogenic AQP4-specific antibodies could arise as a consequence of impaired checkpoints of early B cell tolerance [3, 4]. However, pathogenic AQP4-specific antibodies could also form as consequence of paraneoplastic events ([5-8]), or in sequel to infections (e.g. tuberculosis, different herpes virus infections, Dengue virus infections [9, 10], hepatitis, or events summarized as "common cold" and "feverish infection" (for review see [5]). This suggests the action of viral or bacterial proteins mimicking antibody targets as first initiating events, as seen in patients with Guillain Barré Syndrome $[11,12]$ or some other antibody-driven diseases $[13,14]$. 
Based on such observations we reasoned that one might be able to induce AQP4-reactive antibodies with mimotopes. Mimotopes are linear peptides which can fold themselves into short structural elements [15], and which mimic the target epitope of a given antibody so closely, that they are actually recognized by this antibody as well [16]. They can block the interactions between this antibody and its real target [17], and evoke similar responses when used as immunogens/vaccines [18], even if they do not share amino acid sequences with the recognized target. Most importantly, mimotopes can also mimic conformational epitopes [17, 19-22]. Therefore, they can be used in replacement of antigens which are difficult to isolate, or which lose their correct threedimensional structure along with appropriately displayed conformational epitopes upon isolation [23].

We searched for mimotopes of the conformational AQP4 epitopes recognized by pathogenic AQP4-specific antibodies of NMOSD patients, and used them for the induction of AQP4-reactive antibodies in Lewis rats.

\section{Material and methods Animals}

Lewis rats were used throughout this study. They were obtained from Charles River Wiga (Sulzfeld, Germany) and entered the experiments at an age of 8 weeks. The animals were housed in the Decentral Facilities of the Institute for Biomedical Research (Medical University Vienna) under standardized conditions.

\section{Patient samples}

Plasmapheresates/serum samples from AQP4-antibody positive NMOSD patients were used for NMO-IgG preparations as described previously [24], and were adjusted to a concentration of $10 \mathrm{mg} \mathrm{IgG} / \mathrm{ml}$.

\section{Characterization of NMO-IgG preparations used for mimotope search}

Testing their ability to bind to rat astrocytes. We first produced astrocyte-enriched cultures from neonatal rat brains following standard procedures [25]. Briefly, 0-24h-old Lewis rats were killed and their brains dissected and transferred to RPMI $1640 / 10 \%$ fetal calf serum (FCS). The meninges were removed and the brains mechanically dissociated by gentle pipetting to obtain single cell suspensions which were cultured in poly-llysine-coated culture flasks with RPMI1650/10\% FCS. After 5-7 days, the resulting cultures consisted of a monolayer of astrocytes and fibroblasts, with loosely adherent, ramified microglial cells and glial progenitor cells on top. These cultures were then agitated for $12-15 \mathrm{~h}$ $\left(180 \mathrm{rpm}, 37^{\circ} \mathrm{C}\right)$ to detach the loosely adherent cells, which were then discarded. The firmly adherent cells (mostly astrocytes and fibroblasts) were rinsed with PBS, trypsinized, re-seeded onto poly-l-lysine-coated cover slips, and cultured for an additional 1-2 days in RPMI $1640 / 10 \%$ FCS. About $75 \%$ of all cells in these cultures were astrocytes. The cells were washed three times with RPMI 1640 before the cover slips were transferred to $100 \mu \mathrm{l}$ drops of the NMO-IgG preparations (1:1000 in RPMI 1640/10\% FCS), each in one well of a 12-well plate (Greiner Bio-One, Kremsmünster, Austria) and incubated for $30 \mathrm{~min}$ at $4{ }^{\circ} \mathrm{C}$ in a humidity chamber on a shaking platform $(3 \mathrm{rpm})$. All following reactions were made under protection from light. After washing three times with ice-cold RPMI, donkey-anti-human-Cy3 antibodies (Jackson ImmunoResearch, West Grove, PA, USA, 1:100 in mixed glia medium) was applied for 45 min at $4{ }^{\circ} \mathrm{C}$ in a humidity chamber in the dark. Cells were washed three times with $1 \mathrm{x}$ PBS and then fixed with 4\% PFA for $15 \mathrm{~min}$ at room temperature (RT). After another three times of washing with $1 \mathrm{x}$ PBS, the cells were permeabilized with $0.1 \%$ Triton-X-100 (Sigma-Aldrich) in RPMI/10\% FCS for $5 \mathrm{~min}$ at RT and again washed with $1 \mathrm{x}$ PBS. Then, the cells were incubated with primary antibodies (rabbit-anti-AQP4 and goat-anti-GFAP, 1:100 in PBS/10\% DAKO Real ${ }^{\mathrm{Tm}}$ Antibody Diluent (Agilent Technologies Inc., Santa Carla, CA, USA) overnight at $4{ }^{\circ} \mathrm{C}$ in a humidity chamber on a shaking platform $(3 \mathrm{rpm})$. Afterwards, the cells were washed three times with $1 \mathrm{x}$ PBS and secondary antibodies (donkey-anti-rabbit-Cy 2, 1:150, donkey-antigoat-Cy5, 1:100 in DAKO Wash buffer (Agilent Technologies Inc.) $/ 10 \%$ FCS) were applied for $1 \mathrm{~h}$ at RT. Having washed the cells three times with $1 \mathrm{x}$ PBS, 4', 6diamidino-2-phenylindole (DAPI) (Carl Roth $\mathrm{GmbH}$ und Co KG; 1:10000 in double-distilled water $\left.\left(\mathrm{ddH}_{2} \mathrm{O}\right)\right)$ was applied for $5 \mathrm{~min}$ at RT. After washing with $1 \mathrm{x}$ PBS and with $\mathrm{ddH}_{2} \mathrm{O}$, cover slips were mounted in one drop of Gallate/Geltol (Sigma-Aldrich) on glass slides and stored at $4{ }^{\circ} \mathrm{C}$ under protection from light. The stainings were analyzed using a Leica TCS SP5 setup (Leica Microsystems, CMS-GmbH, Germany). Cy2 signals were detected with an argon laser (488 nm excitation), detection of Cy3 was carried out using a DPSS561 laser and DAPI staining was detected with a 405 Diode laser. Images were edited and auto-adapted for contrast and brightness with Image).

Testing their ability to initiate the formation of astrocyte-destructive lesions. This was done using standard procedures of our laboratory [24, 26]. Briefly, T cell lines against myelin basic protein (MBP, from guinea pig, Sigma) were intraperitoneally injected to induce experimental autoimmune encephalomyelitis (EAE). When the animals started to lose weight as first clinical symptom of EAE, they were intra-peritoneally injected with 1 $\mathrm{ml}$ phosphate buffered saline (PBS) containing either 10 mg NMO-IgG or $10 \mathrm{mg}$ normal human IgG (Subcuvia $^{\mathrm{R}}$ ). 
$24 \mathrm{~h}$ later, the animals were sacrificed with $\mathrm{CO}_{2}$ and perfused with $4 \%$ phosphate buffered paraformaldehyde (PFA). Brains and spinal cords were dissected, immersed for another $18 \mathrm{~h}$ in PFA, and embedded in paraffin.

$2-4 \mu \mathrm{m}$ thick sections were cut on a microtome. The sections were dewaxed in xylol for $30 \mathrm{~min}$, transferred to $96 \%$ ethanol, and incubated in $0.2 \%$ hydrogen peroxide for $30 \mathrm{~min}$ to block endogenous peroxidase. Then, the sections were rehydrated through a descending ethanol series $(96,70,50 \%)$, rinsed in distilled water, and subjected to antigen retrieval by heating them for $60 \mathrm{~min}$ in $10 \mathrm{mM}$ EDTA pH 8.5 in a conventional household steamer. Subsequently, the sections were rinsed in $0.1 \mathrm{M}$ PBS or Tris-buffered saline (TBS) for $60 \mathrm{~min}$, and exposed to $10 \%$ fetal calf serum (FCS) in $1 \mathrm{x}$ DAKO Wash Buffer in PBS for $20 \mathrm{~min}$ at room temperature to reduce non-specific background. Then, immunohistochemical stainings were done essentially as described [24], using polyclonal rabbit anti-rat AQP4 (1:250, Sigma-Aldrich, Vienna, Austria) and the polyclonal rabbit anti-cow glial fibrillary acidic protein (GFAP, cross-reactive with rat; 1 : 3000; DakoCytomation), Immunohistochemistry was completed by incubation with biotinylated donkey antirabbit antibodies (1:2000, Jackson ImmunoResearch) followed by exposure to avidin-peroxidase complex (1: 100 in DB/FCS; Sigma). Labeling was visualized with 3, 3' diaminobenzidine-tetra-hydrochloride (DAB, Sigma) containing $0,01 \%$ hydrogen peroxide. All sections were counterstained with Meyer's hematoxylin, dehydrated and mounted in Eukitt@ (Merck, Darmstadt, Germany).

\section{Mimotope search}

The NMO-IgG preparations I-IV were used for mimotope searches. Details about NMO-IgG titers, age, gender, clinical disease, co-existing autoimmunity, and treatments at the time of sampling are summarized in Table 1.

The NMO-IgG preparations were used together with the phage display peptide library Ph.D.-12 (New England Biolabs (NEB), Ipswich, MA). This library contains phages displaying 5 copies of a single randomized amino acid 12-mer fused via a glycin-glycin-glycin-serin (GGGS) linker to each of the five copies of the outer minor phage coat protein (pIII) of the M13 phage M13KE (information from the manufacturer). The library was essentially used according to NEB's instructions, using three rounds of biopanning by negative selection on human IgG (Subcuvia ${ }^{\mathrm{ru}}$, Baxter, Vienna, Austria) followed by positive selection on NMOIgG (Fig. 1). A detailed description is found in the supplementary information (S1). From aliquots of 98 phage clones binding to NMO-IgG after three rounds of negative/positive selection, and of 8 phage clones randomly picked prior to the selections (for usage as negative controls) DNA was isolated and sent for sequencing (VBC-Biotech Service $\mathrm{GmbH}$, Vienna, Austria). Afterwards, the resulting DNA sequences were translated to amino acid sequences using the ExPASy translate tool (web.expasy.org/translate) to obtain information about the 12 amino acid-long peptides displayed by the analyzed phages. Details about DNA isolation and peptide quality controls are found in the supplementary information S2, S3.

The 12-mer amino acids displayed by the best NMOIgG binders were then synthesized with a C-terminal GGGS extension by Centic Biotec (Heidelberg, Germany) or JPT Peptide Technologies GmbH (Berlin, Germany), with or without N-terminal acetylation and C-terminal amidation. We did not observe any differences between the different peptides containing these

Table 1 Characteristics of the NMO-IgG preparations used for mimotope search

\begin{tabular}{llll}
\hline NMO-IgG & Disease history of patient & characteristics & titer \\
\hline $\mathbf{I}$ & 38 year-old female patient; diagnosed with SLE in 1999, & ANA+ (nuclei+, mitosis+, nucleoli-) \\
& very mild NMO (transverse myelitis) in 2010; samples from & \\
& 2013; patient has antibodies against AQP4 of both IgM and \\
& IgG1 isotypes. Treated with MTP and MMF at time of sampling & \\
& 68 1:10240
\end{tabular}

II 68 year-old female patient with 5 years disease duration. Optic neuritis and thoracic myelitis (march 2010). Weakness of right leg and somnolence with diffuse brain lesions on left hemisphere and diffuse lesions in corpus callosum (july 2011, treated with steroids). Weakness of left leg with thoracic cord relapse (Th2 5), left vision disabled (september 2011).

III 51 year-old female patient with optic neuritis; no episode of

Negative for antibodies against SS-A, SS-B, Cardiolipin, MPO/C-ANCA, thyroglobulin, ribosomal P-protein, Scl-70, cyclic citrullinated peptide; ANAt, anti-dsDNA+,

Negative for ANA 

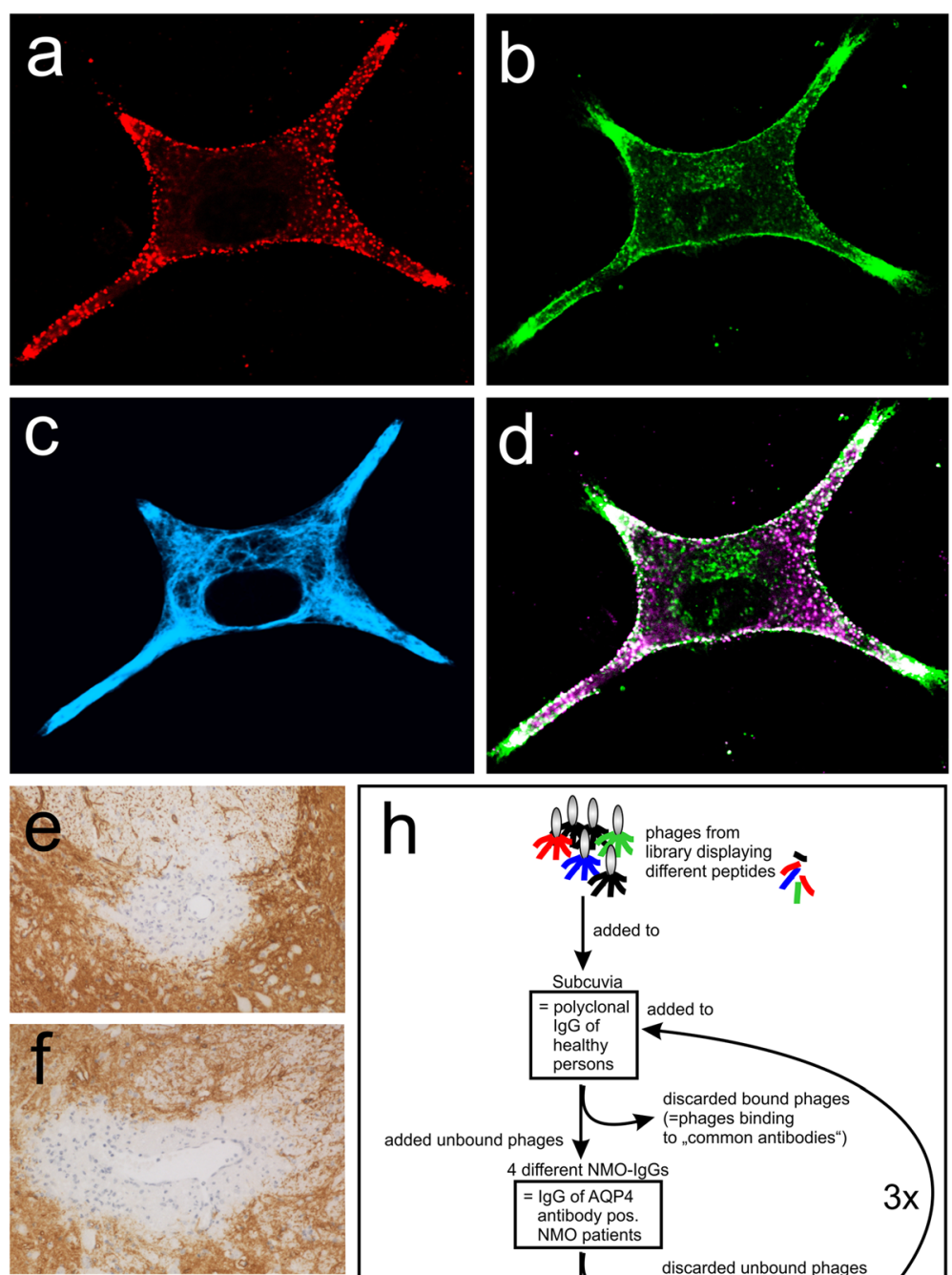

$\downarrow$
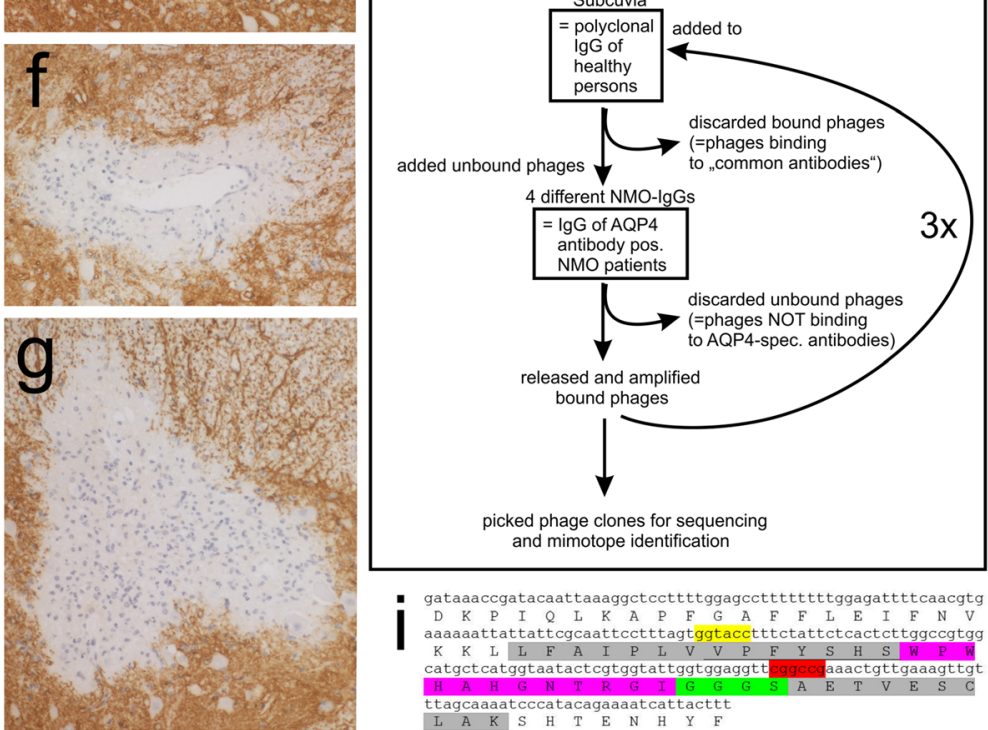

Fig. 1 Characterization of NMO-lgGs used for mimotope search. a-d Immunofluorescence staining of Lewis rat astrocytes and analysis by confocal microscopy. The NMO-IgG preparation IV containing pathogenic AQP4-reactive antibodies recognizing conformational epitopes on the surface of astrocytes (a, red), a commercial AQP4-reactive antibody recognizing intracellular AQP4 epitopes (b, green) and an antibody directed against GFAP (c, blue) were used for stainings. Stainings against surface and intracellular AQP4 epitopes were merged to prove that IV contains AQP4-reactive antibodies reacting with rat AQP4 (d, white). e-f Formation of astrocyte-destructive lesions in experimental NMO. Shown here are spinal cords of Lewis rats injected with myelin basic protein-specific T cells and the NMO-IgG preparations IV (e) III ( $\mathbf{f})$ and I (g). Sections were stained with antibodies against AQP4 to show astrocytes (brown) and counterstained with hematoxylin to show nuclei (blue). $\mathbf{h}$ For each NMO-lgG preparation used, the phage display peptide library Ph.D.-12 was subjected to three rounds of negative selection on human control-lgG (Subcuvia) to deplete phages binding to "common antibodies", and of positive selection on NMO-IgG to enrich for phages binding to the AQP4-reactive antibodies contained within the NMO-IgG preparation. At the end of these selections, bound phages were released, amplified, and sequenced for the identification of the mimotopes. $\mathbf{i}$ Example of sequencing results for mimotope IV-04. The DNA sequence represents the genomic ( + ssDNA in $5^{\prime} \rightarrow 3^{\prime}$ direction. Underneath you see the corresponding amino acid sequence (capital letters). Mimotope flanking regions are shown in gray, restriction enzyme recognitions sites in yellow and red, and the mimotope sequence in magenta 
additional modifications or not, and used both of them without further discrimination for target enrichment ELISA.

To differentiate mimotopes - i.e. peptides binding to the antigen recognition site of AQP4-specific antibodies in the NMO-IgG preparation and thus mimicking the conformational AQP4 epitope - from peptides binding elsewhere onto the antibodies, antibody blocking assays were made (see supplementary information S4 for details).

\section{Mapping conformational epitopes}

The peptides were mapped with Pepsurf (http://pepitope.tau.ac.il/; [28]) onto the 3D structure of human AQP4 (protein data base (pdb) accession number 3GD8) to identify potential epitope sites on AQP4. The BLOSUM62 matrix was used with a gap penalty of -0.5 . Algorithm parameters concerning library type and stop codon modification were adjusted for the Ph.D. ${ }^{\mathrm{m}}-12$ (Phage Display Peptide-12) Library (library type: NNK; stopcodon modification: UAG replaced by glutamine). Only solvent exposed residues were considered to be parts of an epitope, available for antibody binding. A residue is regarded as exposed by Pepsurf if the solvent accessible surface area in the 3D structure is $>5 \%$ of its maximal accessible surface area. This calculation results in an estimated accessibility of the residues. The final alignment represents the best possible path in a defined surface graph. The probability obtaining the same alignment with a random sequence is given by the corresponding $p$-value.

\section{Antibody induction in Lewis rats}

Immunization protocol 1 . Animals (8 rats/peptide) were subcutaneously immunized with mimotope-KLH at 4 different sites along the flanks with a total amount of $200 \mu \mathrm{l}$ of a suspension containing $20 \mu \mathrm{l}$ Alum (Alhydrogel, InvivoGen, San Diego, USA), $20 \mu \mathrm{l}$ 10xPBS, and $160 \mu \mathrm{l}$ peptide (see Table 2 ; stock $5 \mathrm{mg} / \mathrm{ml}$, dissolved in $30 \%$ DMSO), and were boosted bi-weekly with the same suspension, starting 2 weeks after the primary immunization. At the time when the animals were boosted, serum was taken to test for the presence of anti-rat AQP4-antibodies.

The animals were killed by $\mathrm{CO}_{2}$ inhalation, and brains, spinal cords and kidneys prepared for immunohistochemical analysis as outlined above.

Table 2 Amino acid sequences of mimotopes, peptides, and their derivatives for immunization

\begin{tabular}{|c|c|c|c|}
\hline Mimotope ID & $\begin{array}{l}\text { Mimotope: } \\
\text { Amino acid sequences } \\
\text { including GGGS linker }\end{array}$ & $\begin{array}{l}\text { Mimotope-KLH: } \\
\text { Mimotope-keyhole limpet hemocyanin } \\
\text { fusions for immunization protocol } 1\end{array}$ & $\begin{array}{l}\text { Mimotope-AQP4 } 268-285: \\
\text { Mimotopes fused with AQP4-reactive T cell } \\
\text { epitope used for immunization protocol } 2\end{array}$ \\
\hline $1-04$ & WRYHVHPTPFKSGGGS & $\begin{array}{l}\text { WRYHVHPTPFKSGGGSC- keyhole } \\
\text { limpet hemocyanin }\end{array}$ & WRYHVHPTPFKSKAAQQTKGSYMEVEDNRS \\
\hline $\mid-13$ & GPFHFLHHHWSQGGGS & $\begin{array}{l}\text { GPFHFLHHHWSQGGGSC- keyhole } \\
\text { limpet hemocyanin }\end{array}$ & GPFHFLHHHWSQKAAQQTKGSYMEVEDNRS \\
\hline $\mid-18$ & WSSHAHRHNHFRGGGS & - & \\
\hline IV-04 & WPWHAHGNTRGIGGGS & $\begin{array}{l}\text { WPWHAHGNTRGIGGGSC- keyhole } \\
\text { limpet hemocyanin }\end{array}$ & WPWHAHGNTRGIKAAQQTKGSYMEVEDNRS \\
\hline IV-27 & IQYAPGGSYSVIGGGS & - & \\
\hline IV-38 & VKGHWHHLNHANGGGS & - & VKGHWHHLNHANKAAQQTKGSYMEVEDNRS \\
\hline$\|-01$ & FPFWHRTHAWDRGGGS & - & \\
\hline \multirow[t]{2}{*}{|| $\mid-01$} & WSWKHHHPIMPRGGGS & $\begin{array}{l}\text { WSWKHHHPIMPRGGGSC-keyhole } \\
\text { limpet hemocyanin }\end{array}$ & WSWKHHHPIMPRKAAQQTKGSYMEVEDNRS \\
\hline & & $\begin{array}{l}\text { "mix": } \\
\text { I-04 (WRYHVHPTPFKSGGGSC- } \\
\text { keyhole limpet hemocyanin) + } \\
\text { I-13 (GPFHFLHHHWSQGGGSC- } \\
\text { keyhole limpet hemocyanin) + } \\
\text { IV-04 (WPWHAHGNTRGIGGGSC- } \\
\text { keyhole limpet hemocyanin) + } \\
\text { III-01 (WSWKHHHPIMPRGGGSC- } \\
\text { keyhole limpet hemocyanin) }\end{array}$ & - \\
\hline Neg.controls: & & - & - \\
\hline$\|-17$ & HFWGHHRTTSKVGGGS & - & - \\
\hline random peptide L5 & SPRAISSYPLNEGGGS & - & - \\
\hline random peptide L8 & FPTDSLRGDVGMGGGS & - & - \\
\hline
\end{tabular}

There are no matching linear sequences of the mimotopes to human AQP4 loops A (TINWGGTEKPLPVD), C (TPPSVVGGLGVTMVHGNLT) or E (NWENHW) Loop sequences were taken from [29] 
Immunization protocol 2. Animals were subcutaneously immunized at 4 different sites along the flanks with a total amount of $200 \mu \mathrm{l}$ of a 1:1 mixture of mimotope-AQP4 $4_{268-285}$ (Table 2, stock $1 \mathrm{mg} / \mathrm{ml}$ ) in Freund's incomplete adjuvans supplemented with $4 \mathrm{mg}$ / $\mathrm{ml}$ Mycobacterium tuberculosis H37Ra (Complete Freund's adjuvans, CFA). 5-6 weeks later, the animals were boosted with the same antigen/adjuvans mixtures (total amount $200 \mu \mathrm{l}$, distributed over 4 sites along the flanks), and killed 2 weeks later by $\mathrm{CO}_{2}$ inhalation. Blood was taken for serum analysis. Brains, spinal cords, and kidneys were dissected, post-fixed in $4 \%$ paraformaldehyde in phosphate-buffered saline (4\%PFA) for additional $18-24 \mathrm{~h}$ and embedded in paraffin for histological analysis.

Both immunization protocols did not induce any clinical symptoms in the experimental animals.

\section{Titer determinations}

Serum was used to determine the titers of AQP4reactive antibodies in cell-based assays as described, using HEK293 cells transfected with rat or human AQP4 M23 as targets [24, 30].

\section{Identification of IgG subclasses of AQP4-reactive antibodies in live cell-based assays}

IgG subclasses of mimotope-immunized rat sera were investigated using a live cell-based-assay with HEK293 cells expressing rat-AQP4 fused to EmGFP [31]. Sera from four different animals were studied. The mouse monoclonal AQP4 antibody E5415A [32] was used as a positive control. Sera taken from a mimotopeimmunized rat with an antibody titer of zero and from a normal healthy control rat served as negative controls.

HEK293 cells expressing rat AQP4-EmGFP were blocked with goat-IgG $(4 \mu \mathrm{g} / \mathrm{ml}$; Sigma-Aldrich) and subsequently incubated with rat sera diluted 1:20 and 1: 40 in 10\%FCS/PBS (FCS, Gibco; PBS, Sigma-Aldrich) or with the mouse monoclonal AQP4 antibody E5415A $(5 \mu \mathrm{g} / \mathrm{ml}$ in $10 \% \mathrm{FCS} / \mathrm{PBS})$ for $1 \mathrm{~h}$ at $4{ }^{\circ} \mathrm{C}$. After washing three times with $10 \% \mathrm{FCS} / \mathrm{PBS}$, IgG subclasses were determined by incubating with mouse anti-rat IgG1, IgG2a, IgG2b and IgG2c antibodies (1:200 in 10\%FCS/PBS; BioLegend) for $30 \mathrm{~min}$ at $4{ }^{\circ} \mathrm{C}$. Following a washing step cells were incubated with Alexa Fluor 594 labelled goat anti-mouse IgG (1:500 in 10\%FCS/PBS; Invitrogen) at room temperature for $30 \mathrm{~min}$. Dead cells were excluded by DAPI staining (Sigma-Aldrich). Data were analyzed by two investigators (ML and KS).

Studying the ability of mimotope-induced AQP4-reactive antibodies to induce complement-dependent cytotoxicity A live cell-based assay with HEK293 cells expressing ratAQP4 fused to EmGFP was used to analyze antibody- mediated complement activation [31]. Five different rat serum samples were studied together with 7 positive controls (mouse monoclonal AQP4 antibody E5415A, 2 rat sera containing the E5415A antibody, 3 human AQP4-Ab positive NMOSD serum samples and 1 human NMOSD plasmapheresis sample) and 3 negative controls (rat serum, mouse IgG and serum from a mimotope immunized rat with an antibody titer of zero).

Briefly, serum samples and an aliquot of rat complement serum (Dunn Labortechnik, Asbach, Germany) were heat inactivated for $1 \mathrm{~h}$ at $56^{\circ} \mathrm{C}$. HEK293 cells expressing rat-AQP4EmGFP were blocked with goat IgG (Sigma-Aldrich, $4 \mu \mathrm{g} / \mathrm{ml}$ in X-VIVO (Lonza)), washed three times with X-VIVO and subsequently incubated with serum samples (diluted 1:10 in X-VIVO), the monoclonal AQP4 antibody E5415A $(20 \mu \mathrm{g} / \mathrm{ml}$ in XVIVO) or mouse IgG (Sigma-Aldrich, $20 \mu \mathrm{g} / \mathrm{ml}$ in $\mathrm{X}$ VIVO) and with $20 \%$ active or $20 \%$ heat-inactivated rat complement for $90 \mathrm{~min}$ at $37^{\circ} \mathrm{C}$. For detection of the terminal complement complex (TCC) cells were washed three times with X-VIVO and incubated with the murine monoclonal anti-rat C5b-9 antibody (eubio, Vienna, Austria, $2 \mu \mathrm{g} / \mathrm{ml}$ in $\mathrm{X}$-VIVO) for $1 \mathrm{~h}$ at $4{ }^{\circ} \mathrm{C}$. Next, after washing three times with X-VIVO, cells were incubated with Alexa Fluor 594 labelled goat anti-mouse (Invitrogen, diluted 1:500 in X-VIVO) for $30 \mathrm{~min}$ at room temperature. Following a washing step with PBS/ $10 \%$ FCS, dead cells were visualized by DAPI staining (Sigma-Aldrich).

\section{Search for homologous sequences}

Homology searches were made with the basic local alignment search tool (BLAST) (http://blast.ncbi.nlm. nih.gov/Blast.cgi), using the dodecamer peptide sequences as input for the search algorithm blastp (protein-protein BLAST) and the program BLASTP 2.2.0+ to probe the non-redundant database (including all nonredundant GenBank (gb) coding sequences (CDS) translations, the protein data bank (PDB), SwissProt, the protein information resource (PIR) database, and the protein research foundation (PRF) database excluding environmental samples from whole genome shotgun (WGS) projects). Searches were either done unlimited (for the detection of mimotope-related sequences in bacteria/fungi/parasites), or limited to RNA viruses (taxid: 2559587), Mycobacterium tuberculosis typus humanus (taxid: 1773), or Helicobacter pylori (taxid: 2010). Only the top Blast Hits on 100 subject sequences were analyzed for each search.

\section{Statistical analysis}

Statistics were calculated with GraphPad Prism 7.00. 


\section{Results}

The NMO-IgGs used for mimotope search react with AQP4 on rat astrocytes and initiate the formation of astrocyte-destructive lesions in a Lewis rat model of NMOSD

All the NMO-IgGs used for mimotope search derived from patient sera or plasmapheresates which were found positive for pathogenic antibodies against human AQP4 in standard live cell-based diagnostic assays [33] (Table 1). These antibodies also reacted with AQP4 of rat astrocytes (Fig. 1, Supplementary information S5). To test whether the NMOIgG preparations I, III, and IV are also able to initiate astrocyte destructive lesions in our rat model of experimental NMOSD [24], we injected these NMO-IgGs into Lewis rats after opening the blood-brain barrier of these animals with MBP-specific T cells. All three NMO-IgGs initiated the formation of typical perivascular lesions with loss of AQP4 (Fig. 1) and of GFAP reactivity (data not shown) indicative of astrocyte-destruction. For the NMO-IgG preparation II, these features have already been confirmed before [27]. Hence, the NMO-IgG preparations used for mimotope search were proven pathogenic in Lewis rats.

\section{Identification of mimotopes representing extracellular epitopes of human AQP4}

We used the phage display library Ph.D.-12 and 3 alternating rounds of negative selection on control human IgG $\left(\right.$ Subcuvia $\left.^{\mathrm{Tm}}\right)$ to deplete phages with peptides binding to irrelevant antibodies or serum proteins, and of positive selection on single NMO-IgGs to enrich phages displaying peptides binding to the AQP4-reactive antibodies (Fig. 1). At the end of these selections, single phage clones were sequenced to gain information about the amino acid sequences of the phage-displayed 12-mer peptides (Fig. 1). For further studies, peptides were first pre-selected based on high binding rates to NMO-IgG in ELISA (Fig. 2), on their interference with phage-binding to NMO-IgG (Fig. 2), or on their mapping to extracellular loops of human AQP4 (pdb 3GD8) (Fig. 2), before we tested whether the selected peptides represent true mimotopes able to compete with conformational AQP4 epitopes on human AQP4-transfected HEK293 cells for NMO-IgG binding (Fig. 2). None of the tested peptides was able to completely interfere with NMO-IgG binding, and those which were able to interfere at all did so very poorly (Fig. 2, and supplementary information S4). This might be due in part to the polyclonal nature of NMO-IgGs [29, 34], and could also result from higher affinities of the NMO-IgGs for the natural ligand than for the tested peptides. We did not further address this point, but concentrated on peptides which significantly interfered with the binding of AQP4reactive antibodies from at least 1/15 different NMO-IgG preparations (IV-04, II-1, and III-01, Fig. 2 and Table 2), and on those which showed some interference with these
NMO-IgGs in the same tests, even if this did not reach significance (I-04, I-13, and IV-38, Fig. 2 and Table 2). These peptides had a completely different amino acid sequence than the three extracellular loops of AQP4 (Table 2), and were subsequently termed mimotopes. 5 of them (IV-04, III-01, I-04, I-13, and IV-38) were used for the immunization of Lewis rats (Table 2).

\section{Immunization of Lewis rats with AQP4 mimotopes induces the production of AQP4-reactive antibodies which recognize conformational epitopes on the surface of HEK293 cells transfected with rat AQP4, and cross- react with human AQP4}

The animals were immunized with two different protocols. First, we immunized Lewis rats with mimotopeKLH/alum (Table 2), and boosted the animals $4 \mathrm{x}$ with the same immunogen. This approach let to very low AQP4-reactive antibody titers in very few animals: Only $2 / 32$ animals reached antibody titers $>20$ : One animal had titers of $40 / 40 /$ n.d./80 measured 2 weeks apart, the other had titers of 20/80/40/20 in the same time period. All others were essentially negative after the 4th boost.

For the second protocol, we immunized the animals with mimotopes fused to AQP4 ${ }_{268-285}$ which contains two overlapping, highly encephalitogenic $\mathrm{T}$ cell epitopes of the AQP4-response in Lewis rats [35]. Most importantly, the sequence $\mathrm{AQP} 4_{268-285}$ does not contribute to the extracellular loops A, C, and E of AQP4 [29, 36]. We used CFA as adjuvant (Table 2), and boosted the animals 5-6 weeks later with the same immunogen. 2 weeks after boosting, at the time of sacrifice, all animals appeared healthy, and did not display any clinical signs of NMOSD. Histological evaluation revealed that none of the immunized animals had any inflammatory CNS lesion or CNS lesion with AQP4 loss typical for NMOSD (data not shown). We then studied the sera taken at the time of sacrifice, and analyzed them with the same live cell-based assays used for the detection of pathogenic AQP4-reactive antibodies in NMOSD patients [33]. We found AQP4-reactive antibodies above threshold (titer > $20)$ in $3 / 8$ rats immunized with III-01-AQP4 $268-285 /$ CFA, in 3/5 animals immunized with I-13-AQP4 $268-285 /$ CFA, in 4/5 animals immunized with I-04-AQP4 $268-285 /$ CFA, in 3/5 animals immunized with IV-04-AQP4 268 ${ }_{285} / \mathrm{CFA}$, and in 0/4 animals immunized with IV-38AQP4 ${ }_{268-285} /$ CFA (Table 3). The antibodies recognized conformational AQP4 epitopes on the surface of HEK293 cells transfected with human AQP4 M23 (Table 3, Fig. 3, range of titers 40-160), and were also reacting with HEK293 cells transfected with rat AQP4 (Table 3, Fig. 3, range of titers 40-320). With serum from the I-04-AQP4 $268-285 / C F A$ immunization series (anti-rat AQP4 titer 320), we could further confirm binding of the induced antibodies to rat astrocytes 

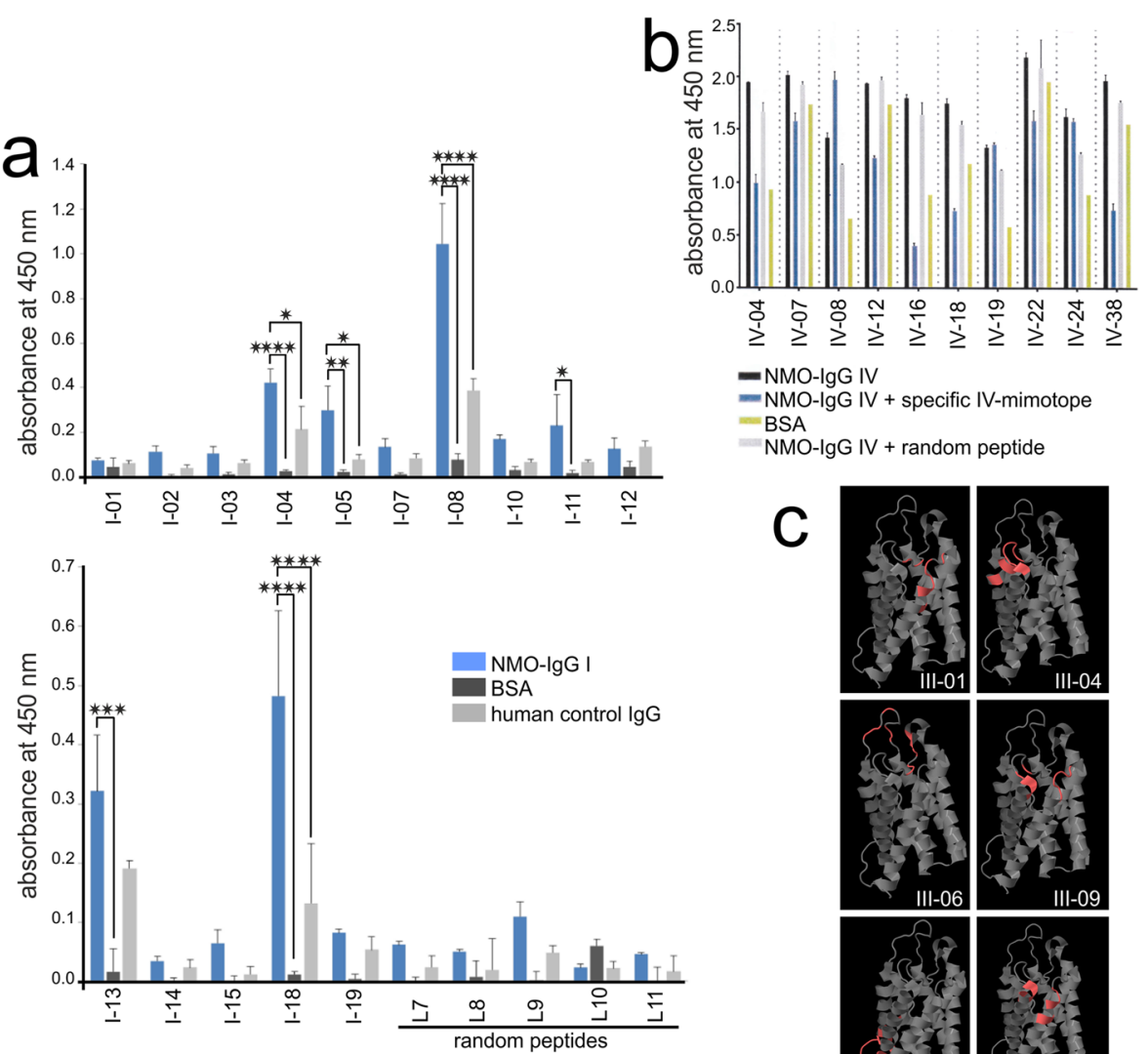

$-\mathrm{NMO}-\operatorname{lgG} \mathrm{IV}$

-NMO-IgG IV + specific IV-mimotope -BSA

NMO-IgG IV + random peptide

C
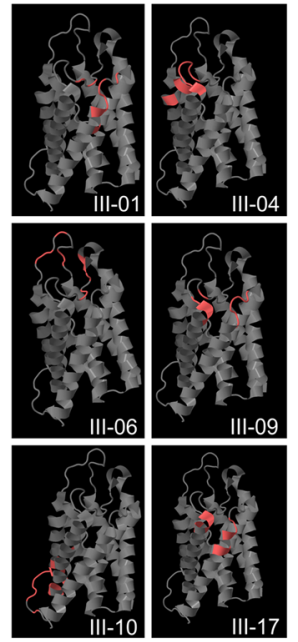

O
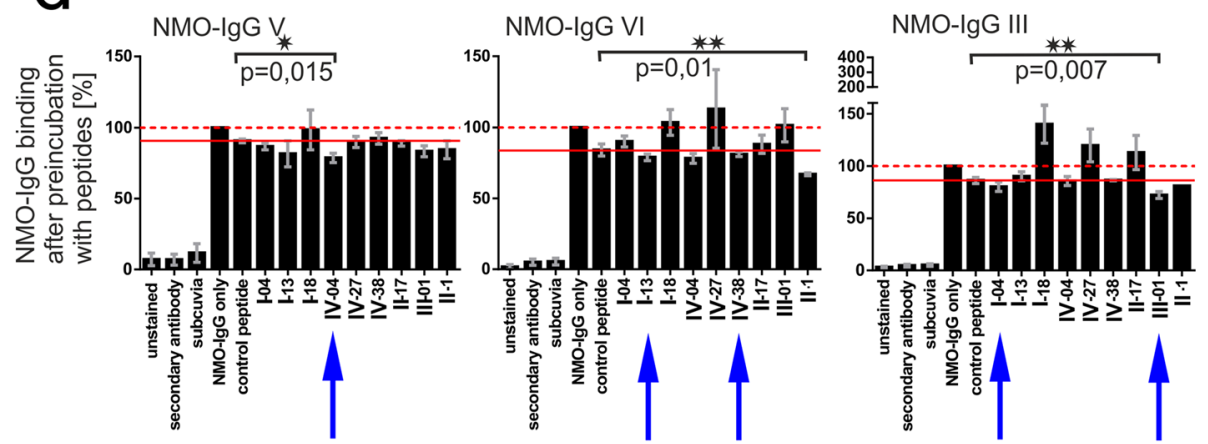

Fig. 2 (See legend on next page.) 
(See figure on previous page.)

Fig. 2 Characterization of phage clones, phage-displayed peptides, and mimotopes. a-c For different NMO-lgG preparations, different experimental approaches were made to narrow down the number of phage-displayed peptides for further studies. a ELISA with single phage clones to evaluate interactions with the NMO-IgG preparation I. Single phage clones after 3 rounds of negative/positive selection (I-01 -> I-19) and 5 randomly picked phage clones without preceeding selection $(L 7->L 11)$ were tested for their ability to react with the NMO-lgG preparation I, BSA, or control-IgG (Subcuvia). Each sample contained $10^{8}$ phages. Data represent three different experiments and are shown as mean + SEM $\left({ }^{*} p<0.05 ;{ }^{* *} p<0.01 ;{ }^{* *} p<0.001 ;{ }^{* * *} p<0.0001\right.$, detected with one-way ANOVA followed by Sidak's multiple comparisons test). $\mathbf{b}$ ELISA to verify that peptides, but not phage particles bind to the NMO-IgG preparation IV. IV was pre-incubated with specific, random, or no synthesized peptides prior to the incubation with peptide-displaying phages. Bound phages were then detected with horse radish peroxidaseconjugated anti-M13 antibodies and TMB substrate, and the absorbance was measured at $450 \mathrm{~nm}$ in an ELISA reader. Data represent triplicates of one experiment and are shown as mean + SEM. c Phage-displayed peptides identified with the NMO-IgG preparation III were mapped onto the 3D structure of human AQP4 (protein data base (pdb) accession number 3GD8) using PepSurf. Extracellular loops are displayed on top of the structure, intracellular parts of the molecule on the bottom of the 3D structure. The final alignment represents the best possible path in a defined surface graph. The probability obtaining the same alignment with a random sequence is given by the corresponding $p$-value. III-01 ( $P$-value: 0.00017), III-04 (P-value: 0.00106), III-06 (P-value: 0.00007), and III-09 (P-value: 0.00028) mapped at least partially to the extracellular loops of AQP4 (red), while III-10 (P-value: 0.00008) and III-17 (P-value: 0.00047) mapped to intracellular or helical structures, respectively. d Selected peptides were tested for their ability to interfere with the binding of AQP4-reactive antibodies of NMO-lgG preparations to AQP4. Flow cytometry of AQP4 M23transfected HEK293A cells reacting with NMO-IgG preparations V, VI, and III pre-incubated with the indicated peptides. Pre-incubation without peptide, or with a random peptide (SPRAISSYPLNEGGGS) served as negative controls. The data shown here are the mean values (+/-SEM) of the percentage of NMO-lgG binding after pre-incubation with peptides, obtained from 4 (V and III) or 5 (VI) independently performed experiments. Please note that the binding of the NMO-IgG preparations pre-incubated without peptide or with random peptides slightly differed from each other. Therefore, we referred to the binding of NMO-lgG without peptide as 100\% (dashed red line) and always also show the percentage of binding of NMO-lgG pre-incubated with random peptide (solid red line). The lower one of these two different values was used as reference for the percentage of blocking achieved with the different peptides. Statistics was calculated using one-tailed, Welch-corrected t-tests. Blue arrows indicate mimotopes used for immunization

(Supplementary information S6). Hence, the AQP4reactive antibodies produced by immunization with mimotope-AQP4 $4_{268-285} / \mathrm{CFA}$ showed cross-reactivity between rat and human AQP4, as is typical for pathogenic AQP4-reactive antibodies found in NMOSD patients $[24,34]$.

\section{Sera of mimotope-AQP4 ${ }_{268-285}$-immunized Lewis rats contain AQP4-reactive antibodies with high and low complement-fixing isotypes}

All serum samples from Lewis rats immunized with the different mimotope-AQP4 ${ }_{268-285}$ (IV-04, III-01, I-04, or I13) contained the AQP4-reactive antibodies as mixtures of low complement-binding isotypes IgG1 and high complement-activating isotypes, predominantly IgG2a and IgG2b [37] (Table 4, supplementary information S7). Despite the presence of AQP4-reactive antibodies with complement-fixing isotypes, the rat sera were unable to activate the complement cascade in vitro, when tested in live cell-based assays using HEK293 cells expressing ratAQP4EmGFP as targets (Fig. 4). The most likely reason for this observation is that the high and low complementfixing AQP4-reactive antibodies compete with each other at the binding sites and thus prevent that the critical threshold of complement-fixation is reached.

Human AQP4 antibody-seropositive NMOSD samples (containing predominantly complement fixing AQP4reactive antibodies of the IgG1 and IgG3 isotype [24]) and the monoclonal E5415A antibody (complement fixing murine IgG2a isotype) used as positive controls showed strong complement activation resulting in deposition of the terminal complement complex (TCC) on cell surfaces, and in higher cell mortality evidenced by increased DAPI staining (Fig. 4). In contrast, incubation with heat-inactivated rat complement or with rat serum and mouse IgG showed no TCC deposition and no activation of the complement cascade.

\section{Similarity of mimotopes to protein sequences of human pathogens}

As shown above, our mimotopes efficiently mimic conformational epitopes of AQP4 for antigen recognition by AQP4-reactive antibodies. Since NMOSD patients may develop clinical disease in sequel to infections, and since molecular mimicry processes of infectious agents were already shown in the development of other autoimmune diseases [38-40], we next analyzed with BLAST whether our AQP4-mimotopes share linear amino acid sequences with proteins of human pathogens. Since antibodies typically recognize 4-12 amino acid-long epitopes, with most robust responses starting with 5 amino acids [41], we postulated that mimotope and pathogen-derived protein must share $\geq 5$ amino acids in continuation plus $\geq 1$ flanking shared amino acid or conservative amino acid substitution. We found 13 highly homologous amino acid sequences of human pathogens (Table 5). Some of these pathogens have been observed more frequently in NMOSD patients, like e.g. H. pylori $[56,64]$ or M. tuberculosis $[57-60,65]$, others were anecdotically reported in NMOSD patients, like e.g. Legionella [66]. We also identified pathogens which have never been described in 
Table 3 Antibody titers obtained with immunization protocol 2

\begin{tabular}{|c|c|c|c|}
\hline $\begin{array}{l}\text { Mimotope } \\
\text { ( } n=\text { number of rats) }\end{array}$ & $\begin{array}{l}\text { Titer } \\
\text { Anti-rat AQP4 }\end{array}$ & $\begin{array}{l}\text { Titer } \\
\text { Anti-human AQP4 }\end{array}$ & $\begin{array}{l}\text { Considered antibody-positive } \\
\text { according to cut-off criteria }\end{array}$ \\
\hline III-01 $(n=8)$ & 20 & 0 & \\
\hline \multirow[t]{7}{*}{$\Delta$} & 0 & 20 & \\
\hline & 10 & 0 & \\
\hline & 80 & 20 & $* * *$ \\
\hline & 0 & 0 & \\
\hline & 40 & 20 & $* * *$ \\
\hline & 0 & 0 & \\
\hline & 160 & 40 & $* * *$ \\
\hline \multirow[t]{4}{*}{ IV-38 $(n=4)$} & 5 & 10 & \\
\hline & 0 & 0 & \\
\hline & 0 & 0 & \\
\hline & 0 & 0 & \\
\hline \multirow[t]{5}{*}{ I-13 $(n=5)$} & 0 & 0 & \\
\hline & 320 & 80 & $* * *$ \\
\hline & 160 & 0 & $* * *$ \\
\hline & 40 & 10 & $* * *$ \\
\hline & 0 & 0 & \\
\hline \multirow[t]{4}{*}{$I-04(n=5)$} & 40 & 10 & $* * *$ \\
\hline & 20 & 20 & \\
\hline & 320 & 160 & $* * *$ \\
\hline & 40 & 40 & $* * *$ \\
\hline$\Delta$ & 320 & 80 & $* * *$ \\
\hline \multirow[t]{5}{*}{$I V-04(n=5)$} & 80 & 10 & $* * *$ \\
\hline & 0 & 0 & \\
\hline & 160 & 0 & $* * *$ \\
\hline & 160 & 40 & $* * *$ \\
\hline & 10 & 0 & \\
\hline
\end{tabular}

***Titers considered positive when single values for anti-rat AQP4 or anti-human AQP4 > 20

$\Delta$ Serum used for staining of rat astrocytes (Supplementary information S6)

the context of NMOSD, like Pseudomonas aeruginosa, Serratia spec, or Enterobacter cloacae complex spec.

The mimotope I-13 shared homology with a 6 amino acid long sequence of Chain A from the enoyl-CoA hydratase of M. tuberculosis (sequence 7 HHHWSQ 12 of I-13 compared to sequence 245 HHHWSH 250 of the M. tuberculosis protein, respectively; Table 5). Since the CFA used for mimotope-AQP4 $4_{268-285}$ immunizations contained $\mathrm{M}$. tuberculosis $\mathrm{H} 37 \mathrm{Ra}$, one could argue that the AQP4-reactive antibodies were induced by a protein of M. tuberculosis instead of the mimotopes. However, the following points argue against this possibility: Firstly, our mimotopes also produced AQP4-reactive antibodies in animals immunized with mimotope-KLH in alum. Secondly, sequences homologous to a $\mathrm{M}$. tuberculosis protein were only seen for I-13, but not for III-01, I-04, or IV-04, which all gave rise to AQP4-reactive antibodies
(Table 5), while $M$. tuberculosis proteins were also present in the immunizations with IV-38-AQP $4_{268-285}$ in CFA, which did not lead to the production of AQP4reactive antibodies (Table 3 ).

\section{Discussion}

Anergy induction, activation-induced cell death or receptor editing are powerful tolerance mechanisms preventing the formation of autoantibodies in the organism [4]. However, autoantibodies may be induced when such checkpoints of early B cell tolerance are impaired [3], or when they are circumvented by proteins from infectious agents mimicking the antibody targets sufficiently well [11-13].

In the current study, we used a phage display library and searched for peptides mimicking the conformational epitopes of AQP4, i.e. for AQP4 mimotopes. We identified 


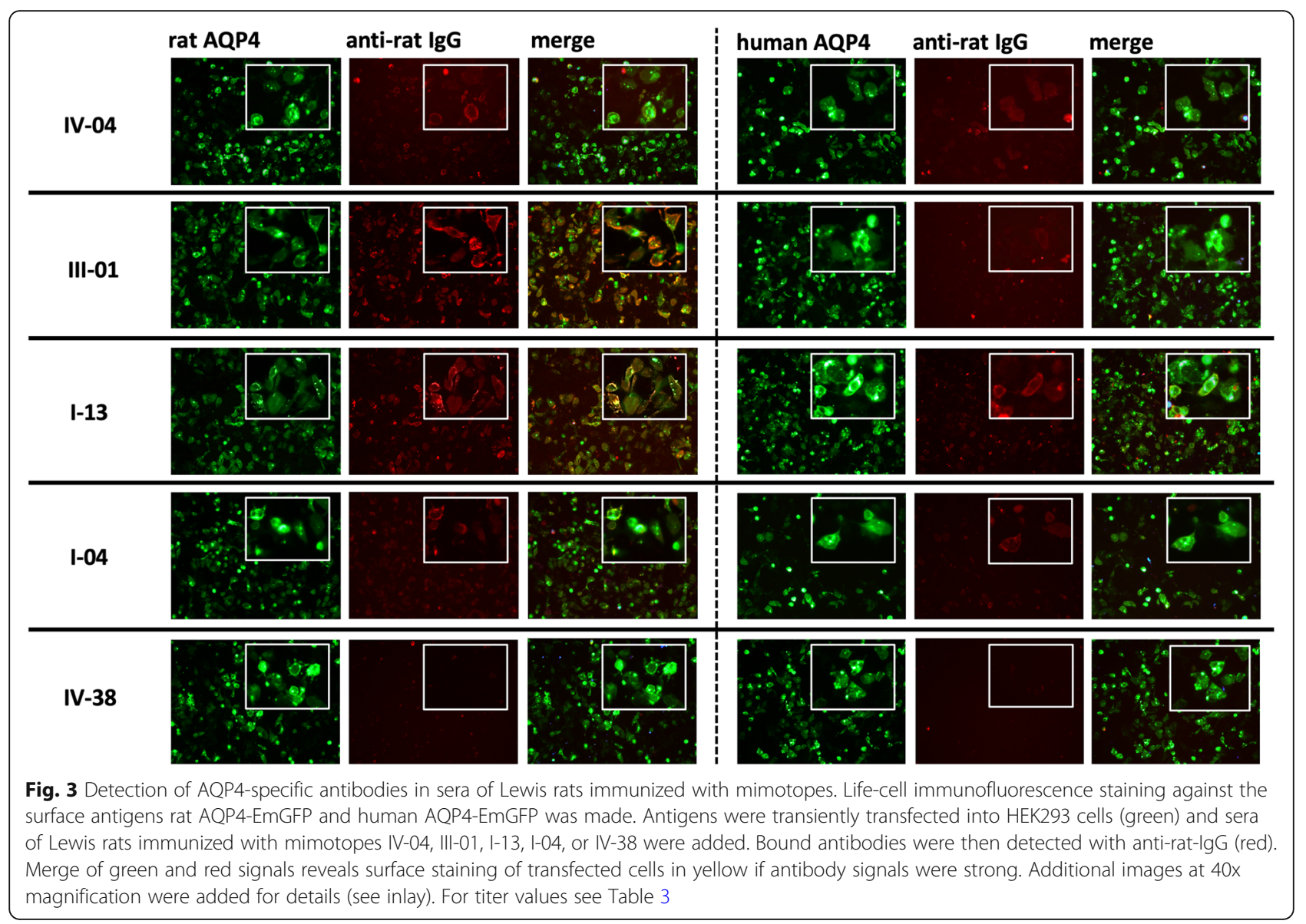

such peptides and show that they do not share homology in amino acid sequence to the extracellular loops of AQP4. At first glance, this seems surprising, but this might be due to the fact that we used polyclonal NMOIgG preparations instead of monoclonal AQP4-specific antibodies for our search, and that different AQP4-specific antibodies may recognize different conformational epitopes formed by the extracellular loops of AQP4. Moreover, mimotopes do not have to share amino acid sequences with

Table 4 Semiquantitative analysis of immunoglobulin $G$ isotypes among AQP4-reactive antibodies raised in mimotopeAQP4 $268-285^{-i m m u n i z e d ~ L e w i s ~ r a t s ~}$

\begin{tabular}{lllll}
\hline & IgG1 & $\operatorname{lgG2a}$ & $\lg$ G2b & $\operatorname{lgG2\mathrm {c}}$ \\
\hline $\mathrm{IV}-04$ & + & + & + & + \\
$\mathrm{III}-01$ & $+(+)$ & +++ & +++ & $+(+)$ \\
$\mathrm{I}-04$ & + & $++(+)$ & $+(+)$ & + \\
$\mathrm{I}-13$ & $++(+)$ & ++ & ++ & ++ \\
\hline
\end{tabular}

+ to +++ indicate reactivity of immunoglobulin $\mathrm{G}$ isotype-specific antibodies to AQP4-reactive antibodies from mimotope- $A Q P 4_{268-285}$-immunized Lewis rats bound to HEK293 cells expressing rat AQP4-EmGFP. The reactivity was rated as + (weak), ++ (moderate), and +++ (strong), respectively their corresponding epitope, but could just share a similar structure. This was seen for example for Rp10-L, a mimotope for the rituximab-specific CD20 epitope [67], or for H98, which induces anti-HER-2-specific antibodies, but does not share homology with HER-2 [68].

Here, we show that the identified peptides were able to compete with conformational AQP4 epitopes for the binding of patient-derived NMO-IgG. We then fused these mimotopes as surrogate $B$ cell epitopes with immunodominant $\mathrm{T}$ cell epitopes of the anti-AQP4 response in Lewis rats and used these mimotopeAQP4 $4_{268-285}$ constructs for the immunization of Lewis rats. These animals produced AQP4-reactive antibodies which bind to living AQP4-expressing cells in the same cell-based assays used for the identification of AQP4antibody seropositive NMOSD patients [33]. Moreover, patient-derived and mimotope-AQP4 ${ }_{268-285}$-induced AQP4-reactive antibodies recognize both human and rat AQP4, undergo T cell help-dependent class switch leading to the production of IgG, consist of different clones (see [34] for human AQP4-reactive antibodies, see the different IgG1 and IgG2a-2c rat immunoglobulins in this study), and contain complement-fixing antibody 


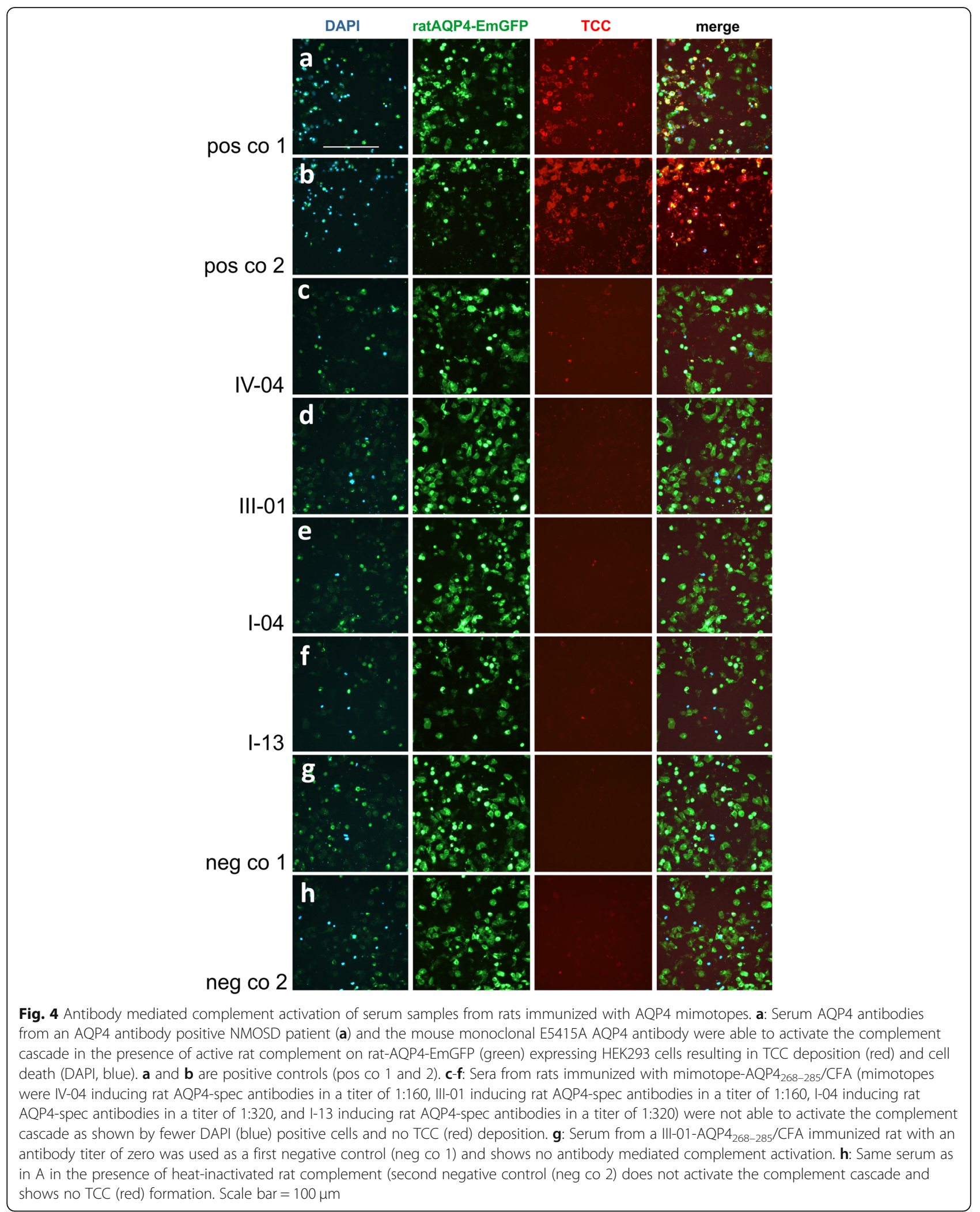


Table 5 Sequence homology between different mimotopes and bacterial/fungal/parasitic proteins. All proteins are located intracellularly, but might be released as a consequence of immune-mediated damage

\begin{tabular}{|c|c|c|c|}
\hline Mimotope & $\begin{array}{l}\text { \# Mimotope sequence \# } \\
\text { Quality of match } \\
\text { \# Organismal protein sequence \# }\end{array}$ & $\begin{array}{l}\text { Protein name } \\
\text { Protein sequence } \\
\text { ID [Organism] }\end{array}$ & $\begin{array}{l}\text { Possible disease } \\
\text { association of bacteria/fungi/ } \\
\text { parasites or presence in human } \\
\text { microbiome }\end{array}$ \\
\hline \multirow[t]{2}{*}{ III-01 } & $\begin{array}{l}5 \text { HHHPIMPR } 12 \\
\text { HH + PIMPR } \\
183 \text { HHQPIMPR } 190\end{array}$ & $\begin{array}{l}\text { DUF3306 domain-containing protein } \\
\text { WP_083797754.1 } \\
\text { [Vibrio Metschnikovii]. }\end{array}$ & $\begin{array}{l}\text { Infections [42, 43]; Isolated cases of } \\
\text { pneumonia [44]. }\end{array}$ \\
\hline & $\begin{array}{l}5 \text { HHHPIMPR } 12 \\
\text { HHHPI + PR } \\
160 \text { HHHPILPR } 167\end{array}$ & $\begin{array}{l}\text { N-succinylarginine dihydrolase } \\
\text { WP_058459851.1 } \\
\text { [Fluoribacter bozemanae = Legionella bozemanae] } \\
\text { Same alignment seen for Legionella anisa and } \\
\text { Legionella longbeachae }\end{array}$ & Legionellosis $[45,46]$. \\
\hline \multirow[t]{2}{*}{$\mathrm{I}-04$} & $\begin{array}{l}3 \text { YHVHPTPF } 10 \\
\text { Y + VHPTPF } \\
519 \text { YQVHPTPF } 526\end{array}$ & $\begin{array}{l}\text { Hypothetical protein CORT_OF01650 } \\
\text { XP_003870521.1 } \\
\text { [Candida orthopsilosis Co 90-125] }\end{array}$ & Rare infections [47] \\
\hline & $\begin{array}{l}3 \text { YHVHPTP } 9 \\
\text { YHVHPTP } \\
560 \text { YHVHPTP } 566 \\
6 \text { HPTPFK } 11 \\
\text { +PTPFK } \\
57 \text { QPTPFK } 62\end{array}$ & $\begin{array}{l}\text { Vacuolar sorting-associated protein } \\
\text { EGC49414.1 } \\
\text { [Histoplasma capsulatum H88];Same alignment } \\
\text { seen forvacuolar protein sorting-associated } \\
\text { protein } 27 \text { EER41546.1 } \\
\text { [Histoplasma capsulatum H143] } \\
\text { Hypothetical protein } \\
\text { WP_080024432.1 } \\
\text { [Helicobacter pylori] }\end{array}$ & $\begin{array}{l}\text { Histoplasmosis [48] } \\
\text { Gastritis, peptid ulcers [49] }\end{array}$ \\
\hline $\mathrm{I}-13$ & $\begin{array}{l}2 \text { PFHFLHH } 8 \\
\text { PFHFLHH } \\
3450 \text { PFHFLHH } 3456 \\
7 \text { HHHWSQ } 12 \\
\text { HHHWS+ } \\
245 \text { HHHWSH } 250\end{array}$ & $\begin{array}{l}\text { RAVE } 1 \text { carboxy-terminal protein } R Q X 74768.1 \\
{[\text { Toxoplasma gondii] }} \\
\text { Chain A, Enoyl-CoA hydratase/isomerase family } \\
\text { protein } \\
4 H C 8 \_A \\
\text { [Mycobacterium tuberculosis] }\end{array}$ & $\begin{array}{l}\text { Toxoplasmosis [50] } \\
\text { Tuberculosis [51] }\end{array}$ \\
\hline IV-04 & $\begin{array}{l}1 \text { WPWHAH-GNTRGI } 12 \\
\text { WPWHAH GN R I } \\
119 \text { WPWHAHLGN-RVI } 130 \\
1 \text { WPWHAHGN } 8 \\
\text { W WHAHGN } \\
393 \text { WAWHAHGN } 400 \\
1 \text { WPWHAHGNTR } 10 \\
\text { W WHAHGN R } \\
243 \text { W-WHAHGNSR } 251 \\
4 \text { HAHGNTRGI } 12 \\
\text { HA GNTRG+ } \\
252 \text { HARGNTRGV } 260 \\
5 \text { AHGNTRGI } 12 \\
\text { A + GNTRG+ } \\
253 \text { AQGNTRGV } 260 \\
1 \text { WPWHAHGN } 8 \\
\text { W WHAHGN } \\
123 \text { WRWHAHGN } 130\end{array}$ & $\begin{array}{l}\text { Glycosyltransferase family } 2 \text { protein } \\
\text { WP_040707114.1 } \\
\text { [Nocardia takedensis]; } \\
\text { Same alignment seen in [Nocardia pneumoniae] } \\
\text { Gentisate 1,2-dioxygenase } \\
\text { VFT64169.1 } \\
\text { [Pseudomonas aeruginosa] } \\
\text { MFS transporter } \\
\text { WP_115184045.1 } \\
\text { [Serratia multispecies, } \\
\text { among them S. plymuthica, S. quinivorans, S. } \\
\text { proteamaculans, S. liquefaciens, S. grimesii] } \\
\text { Hop family adhesin BabA } \\
\text { CEl71366.1 } \\
\text { [Helicobacter pylori] } \\
\text { Hop family adhesin BabA } \\
\text { WP_000716277.1 } \\
\text { [Helicobacter pylori] } \\
\text { cupin domain-containing protein, partial } \\
\text { WP-129361314.1 } \\
\text { [Enterobacter cloacae complex sp. 2DZ2F16B1] }\end{array}$ & $\begin{array}{l}\text { Nocardiosis [52] } \\
\text { Different types of infections [53] } \\
\text { Different types of infections [54] } \\
\text { Gastritis, peptid ulcers [49] } \\
\text { Gastritis, peptid ulcers [49] } \\
\text { Complex includes } \\
\text { common nosocomial pathogens } \\
\text { capable of producing a wide variety } \\
\text { of infections [55] }\end{array}$ \\
\hline
\end{tabular}

Homology searches were made with the basic local alignment search tool (BLAST) and the dodecamer mimotope sequences as input. The combined results of the following searches were pooled for this table: unlimited search, search limited to H. pylori (taxid: 210), search limited to Mycobacterium tuberculosis typus humanus (taxid: 1773), and search limited to RNA viruses (taxid: 2559587). The limited searches were done due to possible associations of NMOSD with infections by H.pylori [56], M. tuberculosis [57-60], and Hepatitis viruses (RNA viruses] [61-63]. The top Blast Hits on 100 subject sequences were analyzed. As cut-off criteria, only continuous sequences $\geq 5$ amino acids plus $\geq 1$ flanking identical amino acid or positive match were considered \# represent the position of the amino acids in the mimotope or protein sequence

amino acids found in both sequences are indicated by letters

$+=$ positive match (conservative substitution)

white space $=$ match with zero/negative score

- = gap 
isotypes (IgG1 and IgG3 in humans [24], IgG2a and IgG2b in rats).

The mimotope-AQP4 $268-285$-immunized animals produced AQP4-reactive antibodies in a titer range of 40320 , which at first glance seems rather low. However, such titers are frequently seen in NMOSD [69], where "low titer patients experience the same disease course as medium-titer and high-titer anti-AQP4 antibody patients" [70]. Low titers of AQP4-reactive antibodies could indicate their depletion from the circulation, for example by their binding to AQP4 expressing cells in the CNS [71] or in peripheral organs [72, 73]. However, we did not see any astrocyte-destructive, antibodyconsuming lesions in the CNS (data not shown), had no evidence for AQP4 loss resulting from antibody binding to astrocytes in the area postrema (supplementary information S8), and could not detect AQP4 loss in kidney collecting duct epithelial cells which otherwise show most robust responses to AQP4-reactive antibodies [73] (data not shown). Hence, these AQP4-antibody seropositive Lewis rats might resemble human patients which can become AQP4-antibody positive months and decades prior to the onset of clinical NMOSD [74, 75].

The generation of AQP4-reactive antibodies in Lewis rats employed immunizations with mimotopeAQP4 ${ }_{268-285}$. This immunogen replaces amino acid sequences of the conformational AQP4 epitope by a mimotope with completely different amino acid sequence, and brings this surrogate $B$ cell epitope in close vicinity to $\mathrm{T}$ cell epitopes which are recognized by $\mathrm{AQP} 4_{268-285}$-specific, highly encephalitogenic $\mathrm{T}$ cells present in the normal immune repertoire of wildtype Lewis rats [76]. Possibly, many different $\mathrm{T}$ cell epitopes would be equally efficient, provided that they drive strong $\mathrm{T}$ cell reactions, and are appropriately restricted by the major histocompatibility complex antigens of the immunized animals. B cell epitopes are often coupled to Keyhole Limpet Hemocyanin (KLH) or to Bovine Serum Albumin (BSA) for immunization. In all these cases, the immune system makes antibodies against the B cell epitope, and $\mathrm{T}$ cell responses against the carrier protein. Hence, the origin of $\mathrm{B}$ and $\mathrm{T}$ cell epitopes do not seem to matter for the antibody responses induced.

Immunizations with mimotope- $\mathrm{T}$ cell epitope fusion peptides have already been successfully employed in the past $[77,78]$, when it was noted that the presence of $\mathrm{T}$ cell epitopes in the fusion peptides positively affected B cell activation, levels of antibody production [77], and affinities of the induced antibodies [78].

Although our mimotope-AQP4 $4_{268-285}$ fusions contained $\mathrm{T}$ cell epitopes for encephalitogenic AQP4 ${ }_{268-}$ $285^{- \text {specific }} \mathrm{T}$ cells [76], we could not detect any $\mathrm{T}$ cell-induced inflammatory lesions in the CNS of the immunized animals (data not shown). It is possible that the time point for sacrificing the animals was too late to capture the window of $\mathrm{T}$ cell infiltration into the CNS. Alternatively, immunization with mimotope$\mathrm{AQP} 4_{268-285}$ could activate AQP4 ${ }_{268-285}$-specific $\mathrm{T}$ cells in numbers sufficient to provide $\mathrm{T}$ cell help to $\mathrm{B}$ cells, but insufficient to overcome the threshold for the induction of CNS inflammation. This line of reasoning is supported by previous studies from our laboratory, were we could readily isolate AQP4 $268-285^{-}$ specific $\mathrm{T}$ cells from $\mathrm{AQP} 4_{268-285} / \mathrm{CFA}$ immunized Lewis rats, but were unable to induce experimental autoimmune encephalomyelitis by these immunizations [76].

Clearly, further strategies are required to improve our AQP4 autoantibody-producing animal model, in particular for studies of antibody entry into the CNS under physiological conditions in vivo, and of mechanisms causing relapse termination and tissue repair. These strategies may include the testing of additional mimotopes, the replacement of $\mathrm{AQP} 4_{268-285}$ by other $\mathrm{T}$ cell epitopes, the use of other adjuvants, other routes of vaccine delivery, refined modes of boosting, and alternative time points for boosting, to elevate antibody titers and affinities, and to cause preferential production of antibodies with high complement-fixing abilities. However, our study provides proof of principle that the strategy to induce AQP4-reactive autoantibodies with mimotopes is feasible.

\section{Supplementary information}

Supplementary information accompanies this paper at https://doi.org/10. 1186/s40478-020-00920-x.

Additional file 1.

\section{Acknowledgments}

We thank Marianne Leisser, Ulrike Köck, Angela Kury and the Core Facility Flow Cytometry, Medical University of Vienna for excellent technical assistance. Florence Pache is thankful to be a participant in the BlH-Charité Clinical Scientist Program funded by the Charite Universitaetsmedizin Berlin and the Berlin Institute of Health.

\section{Authors' contributions}

IT performed flow cytometry and immunization studies; MN made immunization studies, histological analysis, mixed glia cultures for astrocyte analysis and astrocyte stainings for immunofluorescence; BZ, RS, FN,MM,IB,MS were engaged in mimotope search and characterizations; MS, PS contributed to mimotope characterizations; KS and MR determined the antibody titers in the immunized animals, prepared the NMO-lgGs for the current study, and helped ML with isotype identification and complement-mediated cytotoxicity tests; TM, KF, CD, FP, PR, FL, ZI, MIL, JP provided plasmapheresates/sera of NMOSD patients; JLB, MR and HL provided intellectual input; MB designed the study and planned all experiments. IT, MN, and MB wrote the manuscript. All authors read and approved the final manuscript.

\section{Funding}

This work was supported by the Else Kröner-Fresenius-Stiftung (grant number 2013_A283 to MB), the Austrian Science Fund (grant numbers P28476-B30 to MB and P32699B to MR), the Austrian Ministery of Science, 
Research and Economy (BIGWIG-MS to HL and MR), and by Grants-in-aid for Scientific Research of the Ministry of Education, Culture, Sports, Science and Technology of Japan to KF and TM.

\section{Availability of data and materials}

The datasets used and/or analyzed during the current study are available from the corresponding author on reasonable request.

\section{Ethics approval and consent to participate}

The experiments on Lewis rats were approved by the Ethics Commission of the Medical University Vienna and performed with the license of the Austrian Ministry for Science and Research (BMBWF-66.009/0241-WF/II/3b/ 2015; BMBWF-66.009/107-V/3b/2018).

Plasmapheresates/serum samples from NMOSD patients were used by approval of the Regional and National Ethical Committee of Hungary (3893.316-12464/ KK4/2010 and 42341-2/2013/EKU), of the Ethics Committee of the Oxford Radcliffe Hospitals (REC 10/0606/56), of the Regional and National Ethical Committee of Sweden (2013/153-31 Linköping), of the Ethics Committee of Tohoku University School of Medicine (No. 2007-327), of the Ethics Committee of the Medical University of Vienna (No. 1005/2014), and of the Ethics Committee of the Charite Universitaetsmedizin Berlin (EA1/041/14).

\section{Consent for publication}

Not applicable.

\section{Competing interests}

IT, MN, BZ, RS, FN, MM, IB, MS, ML, PR, FL, FP, TM, CD, PS, JLB, HL and MB declare no conflict of interest. JP is partly funded by highly specialised services to run a national congenital myasthenia service and a neuromyelitis service. She has received support for scientific meetings and honorariums for advisory work from Merck Serono, Biogen Idec, Novartis, Teva, Chugai Pharma and Bayer Schering, Alexion, Roche, Genzyme, Medlmmune, Eurolmmun, MedDay, Abide ARGENX, UCB and Viela Bio and grants from Merck Serono, Novartis, Biogen Idec, Teva, Abide, Medlmmune, Bayer Schering, Genzyme, Chugai and Alexion. She has received grants from the MS society, Guthie Jackson Foundation, NIHR, Oxford Health Services Research Committee, EDEN, MRC, GMSI, John Fell and Myaware for research studies. KF reports personal fees from Alexion, Asahi Kasei Medical, Bayer, Biogen, Chugai/Roche, Dainihon Sumitomo, Eisai, Medlmmune/NielaBio, Mitsubishi-Tanabe, Novartis, Ono, Takeda and Teijin, during the conduct of the study; grants from Ministry of Education, Science and Technology of Japan and Ministry of Health, Welfare and Labor of Japan. ZI has received honoraria for clinical endpoint committees in clinical trials of NMOSD; has served on scientific advisory board, has received honoraria for lecturing, and has received support for congress participation from Biogen, Sanofi-Genzyme, Merck, Teva, Roche, and Novartis, respectively. MIL reported being involved in aquaporin 4 testing, and is partially supported by NHS England highly specialised commissioning group for neuromyelitis. MIL has received support for scientific meetings from Novartis and Biogen Idec and honorarium for lectures and advisony work from Biogen Idec, Viela Bio and Argenx. She has received research fellowships from NIHR, University of Oxford and Myaware. MR, KS declare that the University Hospital and Medical University of Innsbruck (Austria) receives payments for antibody assays (MOG, AQP4, and other autoantibodies) and for MOG and AQP4 antibody validation experiments organized by Euroimmun (Lübeck, Germany).

\section{Author details}

${ }^{1}$ Department Neuroimmunology, Medical University Vienna, Center for Brain Research, Spitalgasse 4, A-1090 Vienna, Austria. ${ }^{2}$ Department Pathobiology of the Nervous System, Medical University Vienna, Center for Brain Research, Spitalgasse 4, A-1090 Vienna, Austria. ${ }^{3}$ Clinical Department of Neurology, Medical University of Innsbruck, Innrain 66/2, A-6020 Innsbruck, Austria. ${ }^{4}$ Departments of Multiple Sclerosis Therapeutics and Neurology, Tohoku University Graduate School of Medicine, 1-1 Seiryomachi, Aobaku, Sendai 980-8574, Japan. ${ }^{5}$ Department of Neurology, Neuroscience Program, University of Colorado, Denver, CO 80045, USA. ${ }^{6}$ Department of Clinical and Experimental Medicine, Faculty of Health Sciences, Linköping University, Linköping, Sweden. ${ }^{7}$ Department of Neurology and NeuroCure Clinical Research Center, Charité-Universitätsmedizin Berlin, Berlin, Germany. ${ }^{8}$ Department of Neurology, Medical University Vienna, Vienna, Austria. ${ }^{9}$ Department of Neurology, Odense University Hospital and University of Southern Denmark, Odense, Denmark. ${ }^{10}$ Nuffield Department of Clinical Neurosciences, John Radcliffe Hospital, Oxford, UK.
Received: 11 February 2020 Accepted: 20 March 2020 Published online: 15 April 2020

\section{References}

1. Lennon VA, Kryzer TJ, Pittock SJ, Verkman AS, Hinson SR (2005) IgG marker of optic-spinal multiple sclerosis binds to the aquaporin-4 water channel. J Exp Med 202:473-477

2. Lennon VA, Wingerchuk DM, Kryzer TJ, Pittock SJ, Lucchinetti CF, Fujihara K, Nakashima I, Weinshenker BG (2004) A serum autoantibody marker of neuromyelitis optica: distinction from multiple sclerosis. Lancet 364:2106-2112

3. Cotzomi E, Stathopoulos P, Lee CS, Ritchie AM, Soltys JN, Delmotte FR, Oe T, Sng J, Jiang R, Ma AK, Vander Heiden JA, Kleinstein SH, Levy M, Bennett JL, Meffre E, O'Connor KC (2019) Early B cell tolerance defects in neuromyelitis optica favour anti-AQP4 autoantibody production. Brain 142:1598-1615

4. Vogel AL, Knier B, Lammens K, Kalluri SR, Kuhlmann T, Bennett JL, Korn T (2017) Deletional tolerance prevents AQP4-directed autoimmunity in mice. Eur J Immunol 47:458-469

5. Jarius S, Ruprecht K, Wildemann B, Kuempfel T, Ringelstein M, Geis C, Kleiter I, Kleinschnitz C, Berthele A, Brettschneider J, Hellwig K, Hemmer B, Linker RA, Lauda F, Mayer CA, Tumani H, Melms A, Trebst C, Stangel M, Marziniak M, Hoffmann F, Schippling S, Faiss JH, Neuhaus O, Ettrich B, Zentner C, Guthke K, Hofstadt-van Oy U, Reuss R, Pellkofer H, Ziemann U, Kern P, Wandinger KP, Bergh FT, Boettcher T, Langel S, Liebetrau M, Rommer PS, Niehaus S, Münch C, Winkelmann A, Uwe K, Zettl U, Metz I, Veauthier C, Sieb JP, Wilke C, Hartung HP, Aktas O, Paul F (2012) Contrasting disease patterns in seropositive and seronegative neuromyelitis optica: A multicentre study of 175 patients. J Neuroinflammation 9:14

6. Jin H, Hao H, Nan D, Luo J, Wang L, Gao F, Huang Y (2019) Neuromyelitis optica spectrum disorder coincident with renal clear cell carcinoma: a case report. Medicine (Baltimore) 98:e14229

7. Beauchemin P, lorio R, Traboulsee AL, Field T, Tinker AV, Carruthers RL (2018) Paraneoplastic Neuromyelitis Optica Spectrum disorder: a single center cohort description with two cases of histological validation. Mult Scler Relat Disord 20:37-42

8. Liao W, Li C, Tang Y, Huang F, Kuang H, Liang S, Yang Y (2019) Aquaporin-4 antibody positive short transverse myelitis associated with breast cancer. Mult Scler Relat Disord 30:119-122

9. Miranda de Sousa A, Puccioni-Sohler M, Dias Borges A, Fernandes Adorno L, Papais Alvarenga M, Papais Alvarenga RM (2006) Post-dengue neuromyelitis optica: case report of a Japanese-descendent Brazilian child. J Infect Chemother 12:396-398

10. Rezza G (2012) Aedes albopictus and the reemergence of dengue. BMC Public Health 12:72

11. Rhodes KM, Tattersfield AE (1982) Guillain-Barre syndrome associated with Campylobacter infection. Br Med J (Clin Res Ed) 285:173-174

12. Cao-Lormeau VM, Blake A, Mons S, Lastere S, Roche C, Vanhomwegen J, Dub T, Baudouin L, Teissier A, Larre P, Vial AL, Decam C, Choumet V, Halstead SK, Willison HJ, Musset L, Manuguerra JC, Despres P, Fournier E, Mallet HP, Musso D, Fontanet A, Neil J, Ghawché F (2016) Guillain-Barre syndrome outbreak associated with Zika virus infection in French Polynesia: a case-control study. Lancet 387:1531-1539

13. Tanaka T, Zhang W, Sun Y, Shuai Z, Chida AS, Kenny TP, Yang GX, Sanz I, Ansari A, Bowlus CL, Ippolito GC, Coppel RL, Okazaki K, He XS, Leung PSC, Gershwin ME (2017) Autoreactive monoclonal antibodies from patients with primary biliary cholangitis recognize environmental xenobiotics. Hepatology 66:885-895

14. Gonciarz W, Matusiak A, Rudnicka K, Rechcinski T, Chalubinski M, Czkwianianc E, Broncel M, Gajewski A, Chmiela M (2019) Autoantibodies to a specific peptide epitope of human Hsp60 (ATVLA) with homology to Helicobacter pylori HspB in H. pylori-infected patients. APMIS 127:139-149

15. Inc. NEB ${ }^{R}$ Ph.D..$^{\text {M. }}$. Phage Display Libraries Instruction Manual Version 2018, $3011 / 18: 29$

16. Gevorkian G, Manoutcharian K, Govezensky T, Cano JA, Dominguez V, Santamaria H, Larralde C (2000) Identification of mimotopes of platelet autoantigens associated with autoimmune thrombocytopenic purpura. J Autoimmun 15:33-40

17. El-Attar LM, Partidos CD, Howard CR (2010) A peptide mimotope of hepatitis $C$ virus $E 2$ protein is immunogenic in mice and block human antiHCV sera. J Med Virol 82:1655-1665

18. Riemer $A B$, Kurz H, Klinger M, Scheiner O, Zielinski CC, Jensen-Jarolim E (2005) Vaccination with cetuximab mimotopes and biological properties of 
induced anti-epidermal growth factor receptor antibodies. J Natl Cancer Inst 97:1663-1670

19. Gazarian TG, Selisko B, Gurrola GB, Hernandez R, Possani LD, Gazarian KG (2003) Potential of peptides selected from random phage-displayed libraries to mimic conformational epitopes: a study on scorpion toxin $\mathrm{Cn} 2$ and the neutralizing monoclonal antibody BCF2. Comb Chem High Throughput Screen 6:119-132

20. Gustafsson E, Haas PJ, Walse B, Hijnen M, Furebring C, Ohlin M, van Strijp $J A$, van Kessel KP (2009) Identification of conformational epitopes for human IgG on Chemotaxis inhibitory protein of Staphylococcus aureus. BMC Immunol 10:13

21. Untersmayr E, Szalai K, Riemer AB, Hemmer W, Swoboda I, Hantusch B, Schöll I, Spitzauer S, Scheiner O, Jarisch R, Boltz-Nitulescu G, Jensen-Jarolim E (2006) Mimotopes identify conformational epitopes on parvalbumin, the major fish allergen. Mol Immunol 43:1454-1461

22. Rodi DJ, Janes RW, Sanganee HJ, Holton RA, Wallace BA, Makowski L (1999) Screening of a library of phage-displayed peptides identifies human bcl-2 as a taxol-binding protein. J Mol Biol 285:197-203

23. Kumar S, Hinks JA, Maman J, Ravirajan CT, Pearl LH, Isenberg DA (2011) p185, an immunodominant epitope, is an autoantigen mimotope. J Biol Chem 286:26220-26227

24. Bradl M, Misu T, Takahashi T, Watanabe M, Mader S, Reindl M, Adzemovic M, Bauer J, Berger T, Fujihara K, Itoyama Y, Lassmann H (2009) Neuromyelitis optica: pathogenicity of patient immunoglobulin in vivo. Ann Neurol 66: 630-643

25. Sharma R, Fischer MT, Bauer J, Felts PA, Smith K, Misu T, Fujihara K, Bradl M, Lassmann $\mathrm{H}$ (2010) Inflammation induced by innate immunity in the central nervous system leads to primary astrocyte dysfunction followed by demyelination. Acta Neuropathol 120:223-236

26. Pohl M, Kawakami N, Kitic M, Bauer J, Martins R, Fischer MT, MachadoSantos J, Mader S, Ellwart JW, Misu T, Fujihara K, Wekerle H, Reindl M, Lassmann H, Bradl M (2013) T cell-activation in neuromyelitis optica lesions plays a role in their formation. Acta Neuropathol Commun 1:85

27. Kurosawa K, Misu T, Takai Y, Sato DK, Takahashi T et al (2015) Severely exacerbated neuromyelitis optica rat model with extensive astrocytopathy by high affinity anti-aquaporin-4 monoclonal antibody. Acta Neuropathol Commun 3:82

28. Mayrose I, Shlomi T, Rubinstein ND, Gershoni JM, Ruppin E, Sharan R, Pupko $T$ (2007) Epitope mapping using combinatorial phage-display libraries: a graph-based algorithm. Nucleic Acids Res 35:69-78

29. Owens GP, Ritchie A, Rossi A, Schaller K, Wemlinger S, Schumann H, Shearer A, Verkman AS, Bennett JL (2015) Mutagenesis of the aquaporin 4 extracellular domains defines restricted binding patterns of pathogenic neuromyelitis optica lgG. J Biol Chem 290:12123-12134

30. Mader S, Lutterotti A, Di Pauli F, Kuenz B, Schanda K, Aboul-Enein F, Khalil M, Storch MK, Jarius S, Kristoferitsch W, Berger T, Reindl M (2010) Patterns of antibody binding to aquaporin-4 isoforms in neuromyelitis optica. PLoS One 5:e10455

31. Mader S, Gredler V, Schanda K, Rostasy K, Dujmovic I et al (2011) Complement activating antibodies to myelin oligodendrocyte glycoprotein in neuromyelitis optica and related disorders. J Neuroinflammation 8:184

32. Huang $P$, Takai $Y$, Kusano-Arai O, Ramadhanti J, Iwanari H, Miyauchi T, Sakihama T, Han JY, Aoki M, Hamakubo T, Fujihara K, Yasui M, Abe Y (2016) The binding property of a monoclonal antibody against the extracellular domains of aquaporin-4 directs aquaporin-4 toward endocytosis. Biochem Biophys Rep 7:77-83

33. Waters P, Reindl M, Saiz A, Schanda K, Tuller F, Kral V, Nytrova P, Sobek O, Nielsen HH, Barington T, Lillevang ST, Illes Z, Rentzsch K, Berthele A, Berki T, Granieri L, Bertolotto A, Giometto B, Zuliani L, Hamann D, van Pelt ED, Hintzen R, Höftberger R, Costa C, Comabella M, Montalban X, Tintoré M, Siva A, Altintas A, Deniz G, Woodhall M, Palace J, Paul F, Hartung HP, Aktas O, Jarius S, Wildemann B, Vedeler C, Ruiz A, Leite Ml, Trillenberg P, Probst M, Saschenbrecker S, Vincent A, Marignier R (2016) Multicentre comparison of a diagnostic assay: aquaporin-4 antibodies in neuromyelitis optica. J Neurol Neurosurg Psychiatry 87:1005-1015

34. Bennett JL, Lam C, Kalluri SR, Saikali P, Bautista K, Dupree C, Glogowska M, Case D, Antel JP, Owens GP, Gilden D, Nessler S, Stadelmann C, Hemmer B (2009) Intrathecal pathogenic anti-aquaporin-4 antibodies in early neuromyelitis optica. Ann Neurol 66:617-629

35. Oji S, Nicolussi EM, Kaufmann N, Zeka B, Schanda K, Fujihara K, Illes Z, Dahle C, Reindl M, Lassmann H, Bradl M (2016) Experimental Neuromyelitis Optica induces a type I interferon signature in the spinal cord. PLoS One 11: e0151244

36. Graber DJ, Levy M, Kerr D, Wade WF (2008) Neuromyelitis optica pathogenesis and aquaporin 4. J Neuroinflammation 5:22

37. Medgyesi GA, Miklos K, Kulics J, Fust G, Gergely J, Bazin H (1981) Classes and subclasses of rat antibodies: reaction with the antigen and interaction of the complex with the complement system. Immunology 43:171-176

38. Yuki N, Susuki K, Koga M, Nishimoto Y, Odaka M, Hirata K, Taguchi K, Miyatake T, Furukawa K, Kobata T, Yamada M (2004) Carbohydrate mimicry between human ganglioside GM1 and campylobacter jejuni lipooligosaccharide causes Guillain-Barre syndrome. Proc Natl Acad Sci U S A 101:11404-11409

39. Caporale CM, Capasso M, Luciani M, Prencipe V, Creati B, Gandolfi P, De Angelis MV, Di Muzio A, Caporale V, Uncini A (2006) Experimental axonopathy induced by immunization with campylobacter jejuni lipopolysaccharide from a patient with Guillain-Barre syndrome. J Neuroimmunol 174:12-20

40. Heyma P, Harrison LC, Robins-Browne R (1986) Thyrotrophin (TSH) binding sites on Yersinia enterocolitica recognized by immunoglobulins from humans with Graves' disease. Clin Exp Immunol 64:249-254

41. Buus S, Rockberg J, Forsstrom B, Nilsson P, Uhlen M, Schafer-Nielsen C (2012) High-resolution mapping of linear antibody epitopes using ultrahighdensity peptide microarrays. Mol Cell Proteomics 11:1790-1800

42. Pariente Martin M, Escribano Garaizabal E, Liria Sanchez PJ, Crespo Sanchez MD (2008) Vibrio metschnikovii from a human infected leg ulcer. Rev Inst Med Trop Sao Paulo 50:311-312

43. Jensen J, Jellinge ME (2014) Severe septic shock and cardiac arrest in a patient with Vibrio metschnikovii: a case report. J Med Case Rep 8:348

44. Wallet F, Tachon M, Nseir S, Courcol RJ, Roussel-Delvallez M (2005) Vibrio metschnikovii pneumonia. Emerg Infect Dis 11:1641-1642

45. Amemura-Maekawa J, Kura F, Chida K, Ohya H, Kanatani Jl, Isobe J, Tanaka S, Nakajima H, Hiratsuka T, Yoshino S, Sakata M, Murai M, Ohnishi M (2018) Working Group for Legionella in Japan: Legionella pneumophila and Other Legionella Species Isolated from Legionellosis Patients in Japan between 2008 and 2016. Appl Environ Microbiol 84

46. Svarrer CW, Uldum SA (2012) The occurrence of Legionella species other than Legionella pneumophila in clinical and environmental samples in Denmark identified by mip gene sequencing and matrix-assisted laser desorption ionization time-of-flight mass spectrometry. Clin Microbiol Infect 18:1004-1009

47. Riccombeni A, Vidanes G, Proux-Wera E, Wolfe KH, Butler G (2012) Sequence and analysis of the genome of the pathogenic yeast Candida orthopsilosis. PLoS One 7:e35750

48. Mittal J, Ponce MG, Gendlina I, Nosanchuk JD (2018) Histoplasma Capsulatum: mechanisms for pathogenesis. Curr Top Microbiol Immunol 422:157-191

49. Marshall BJ (1993) Helicobacter pylori: a primer for 1994. Gastroenterologist 1:241247

50. Dard C, Fricker-Hidalgo H, Brenier-Pinchart MP, Pelloux H (2016) Relevance of and new developments in serology for toxoplasmosis. Trends Parasitol 32:492-506

51. Yadav J, Verma S, Chaudhary D, Jaiwal PK, Jaiwal R (2019) Tuberculosis: current status, diagnosis, treatment and development of novel vaccines. Curr Pharm Biotechnol 20:446-458

52. Lee TG, Jin WJ, Jeong WS, Moon SH, Kwon TG, Lee SK, Kang HS, Hwangbo H (2017) Primary cutaneous Nocardiosis caused by Nocardia takedensis. Ann Dermatol 29:471-475

53. Lynch JP 3rd, Zhanel GG, Clark NM (2017) Emergence of antimicrobial resistance among Pseudomonas aeruginosa: implications for therapy. Semin Respir Crit Care Med 38:326-345

54. Mahlen SD (2011) Serratia infections: from military experiments to current practice. Clin Microbiol Rev 24:755-791

55. Annavajhala MK, Gomez-Simmonds A, Uhlemann AC (2019) Multidrugresistant Enterobacter cloacae Complex emerging as a global, Diversifying Threat. Front Microbiol 10:44

56. Kira Jl, Isobe N (2019) Helicobacter pylori infection and demyelinating disease of the central nervous system. J Neuroimmunol 329:14-19

57. Brey N, Henning F (2014) Relapsing neuromyelitis optica temporally related to recurrent pulmonary tuberculosis. Int J Tuberc Lung Dis 18:632-633

58. Rafai MA, Boulaajaj FZ, Gynerane M, El Moutawakkil B, Slassi I (2010) Deviclike syndrome in the course of pulmonary tuberculosis. Acta Neurol Belg 110:196-200 
59. Siddiqi SA, Hashmi M, Azmat Z, Mustafa S, Siddiqui KA (2012) Pulmonary tuberculosis with neuromyelitis optica: an uncommon association of a common disease. J Coll Physicians Surg Pak 22:527-528

60. Sridhar S, Chan JF, Yuen KY (2014) Fatal anti-aquaporin-4 seropositive neuromyelitis optica spectrum disorder in tuberculosis. BMC Infect Dis 14: 470

61. Mangioni D, Soria A, Brighina L, Bandera A, Ferrarese C, Gori A (2014) A case of classic neuromyelitis optica (Devic's syndrome) triggered by pegylatedinterferon alpha. BMC Pharmacol Toxicol 15:56

62. Usmani N, McCarthy M, Rammohan KW, Ortega MR (2014) Fulminant myelitis with $\mathrm{NMO} \operatorname{lgG}$ antibody following treatment with interferon alpha. J Neurol 261:240-241

63. Liu J, Xu L, Chen ZL, Li M, Yi H, Peng FH (2018) Comprehensive analysis of patients with neuromyelitis optica spectrum disorder (NMOSD) combined with chronic hepatitis $\mathrm{B}(\mathrm{CHB})$ infection and seropositive for anti-aquaporin4 antibody. Bosn J Basic Med Sci 18:35-42

64. Li W, Minohara M, Piao H, Matsushita T, Masaki K, Matsuoka T, Isobe N, Su Jل J Ohyagi Y, Kira J (2009) Association of anti-helicobacter pylori neutrophilactivating protein antibody response with anti-aquaporin-4 autoimmunity in Japanese patients with multiple sclerosis and neuromyelitis optica. Mult Scler 15:1411-1421

65. Apetse K, Diatewa JE, Dongmo Tajeuna JJ, Dansou YM, Bakoudissa R, Waklatsi KP, Kombate D, Assogba K, Balogou AAK (2019) Case report: an area postrema syndrome revealing a neuromyelitis optica spectrum disorder associated with central nervous system tuberculosis in a young Togolese (black African) woman. BMC Neurol 19:58

66. Rehman M (2019) BL: an atypcial NMO presentation with locked-in syndrome. Neurology 92:P1.2-P012

67. Perosa F, Favoino E, Caragnano MA, Dammacco F (2005) CD20 mimicry by a mAb rituximab-specific linear peptide: a potential tool for active immunotherapy of autoimmune diseases. Ann N Y Acad Sci 1051:672-683

68. Riemer AB, Klinger M, Wagner S, Bernhaus A, Mazzuchelli L, Pehamberger $H$, Scheiner O, Zielinski CC, Jensen-Jarolim E (2004) Generation of peptide mimics of the epitope recognized by trastuzumab on the oncogenic protein her-2/neu. J Immunol 173:394-401

69. Takahashi T, Fujihara K, Nakashima I, Misu T, Miyazawa I, Nakamura M Watanabe S, Shiga Y, Kanaoka C, Fujimori J, Sato S, Itoyama Y (2007) Antiaquaporin-4 antibody is involved in the pathogenesis of NMO: a study on antibody titre. Brain 130:1235-1243

70. Kessler RA, Mealy MA, Jimenez-Arango JA, Quan C, Paul F, López R, Hopkins S, Levy M (2017) Anti-aquaporin-4 titer is not predictive of disease course in neuromyelitis optica spectrum disorder: a multicenter cohort study. Mult Scler Relat Disord 17:198-201

71. Aboulenein-Djamshidian F, Hoftberger R, Waters P, Krampla W, Lassmann H, Budka H, Vincent A, Kristoferitsch W (2015) Reduction in serum aquaporin-4 antibody titers during development of a tumor-like brain lesion in a patient with neuromyelitis optica: a serum antibody-consuming effect? J Neuropathol Exp Neurol 74:194-197

72. Ratelade J, Bennett JL, Verkman AS (2011) Intravenous neuromyelitis optica autoantibody in mice targets aquaporin-4 in peripheral organs and area postrema. PLoS One 6:e27412

73. Hillebrand S, Schanda K, Nigritinou M, Tsymala I, Bohm D, Peschl P, Takai Y, Fujihara K, Nakashima I, Misu T, Reindl M, Lassmann H, Bradl M (2019) Circulating AQP4-specific auto-antibodies alone can induce neuromyelitis optica spectrum disorder in the rat. Acta Neuropathol 137:467-485

74. Nishiyama S, Ito T, Misu T, Takahashi T, Kikuchi A, Suzuki N, Jin K, Aoki M, Fujihara K, Itoyama Y (2009) A case of NMO seropositive for aquaporin-4 antibody more than 10 years before onset. Neurology 72:1960-1961

75. Leite MI, Coutinho E, Lana-Peixoto M, Apostolos S, Waters P, Sato D, Melamud L, Marta M, Graham A, Spillane J, Villa AM, Callegaro D, Santos E, da Silva AM, Jarius S, Howard R, Nakashima I, Giovannoni G, Buckley C, Hilton-Jones D, Vincent A, Palace J (2012) Myasthenia gravis and neuromyelitis optica spectrum disorder: a multicenter study of 16 patients. Neurology 78:1601-1607

76. Zeka B, Hastermann M, Hochmeister S, Kogl N, Kaufmann N, Schanda K, Mader S, Misu T, Rommer P, Fujihara K, Illes Z, Leutmezer F, Sato DK, Nakashima I, Reindl M, Lassmann H, Bradl M (2015) Highly encephalitogenic aquaporin 4-specific T cells and NMO-lgG jointly orchestrate lesion location and tissue damage in the CNS. Acta Neuropathol 130:783-798
77. Olszewska W, Obeid OE, Steward MW (2000) Protection against measles virus-induced encephalitis by anti-mimotope antibodies: the role of antibody affinity. Virology 272:98-105

78. Shaw DM, Stanley CM, Partidos CD, Steward MW (1993) Influence of the Thelper epitope on the titre and affinity of antibodies to B-cell epitopes after co-immunization. Mol Immunol 30:961-968

\section{Publisher's Note}

Springer Nature remains neutral with regard to jurisdictional claims in published maps and institutional affiliations.
Ready to submit your research? Choose BMC and benefit from:

- fast, convenient online submission

- thorough peer review by experienced researchers in your field

- rapid publication on acceptance

- support for research data, including large and complex data types

- gold Open Access which fosters wider collaboration and increased citations

- maximum visibility for your research: over $100 \mathrm{M}$ website views per year

At BMC, research is always in progress.

Learn more biomedcentral.com/submissions 